NBER WORKING PAPER SERIES

\title{
LIQUIDITY, EFFICIENCY AND BANK BAILOUTS
}

\author{
Gary Gorton \\ Lixin Huang \\ Working Paper 9158 \\ http://www.nber.org/papers/w9158 \\ NATIONAL BUREAU OF ECONOMIC RESEARCH \\ 1050 Massachusetts Avenue \\ Cambridge, MA 02138 \\ September 2002
}

We thank Franklin Allen, Jack Kareken, Richard Kihlstrom, and seminar participants at University of Minnesota and the Federal Reserve Bank of New York for comments and suggestions. The views expressed herein are those of the authors and not necessarily those of the National Bureau of Economic Research.

(C) 2002 by Gary Gorton and Lixin Huang. All rights reserved. Short sections of text, not to exceed two paragraphs, may be quoted without explicit permission provided that full credit, including (C) notice, is given to the source. 
Liquidity, Efficiency and Bank Bailouts

Gary Gorton and Lixin Huang

NBER Working Paper No. 9158

September 2002

JEL No. G21, E58

\section{ABSTRACT}

Why do governments bailout banking systems in distress? We argue that the government can efficiently provide liquidity. We present a general equilibrium model in which not all assets can be used to purchase all other assets at every date. At some dates agents want to sell projects or securities. The only buyers are agents who have previously opportunistically invested in otherwise dominated assets because only these ("liquid") assets can be used to purchase the projects or securities. The market price of the projects or securities sold depends on the supply of liquidity, which is determined in general equilibrium. The supply of liquidity is not perfectly elastic, so asset prices can deviate from "efficient market" prices, that is, the conditional expectation of the asset payoff. While private liquidity provision is socially beneficial since it allows valuable reallocations, it is also socially costly since liquidity suppliers could have made more efficient investments ex ante. As a result, there is a potential role for the government to supply liquidity by issuing government securities, backed by tax revenue. Government bailouts of banking systems are an example of such public liquidity provision.

\author{
Gary Gorton \\ Department of Finance \\ The Wharton School \\ University of Pennsylvania \\ Philadelphia, PA 19104 \\ and NBER \\ gorton@wharton.upenn.edu
}

\author{
Lixin Huang \\ Department of Economics \\ University of Pennsylvania \\ Philadelphia, PA 19104
}


I. Introduction

In the early 1980s high interest rates caused many U.S. savings and loan institutions to become economically distressed. ${ }^{1}$ But, what was to become the thrift crisis in the late 1980 s has, in large part, been attributed to the fact that insolvent institutions were allowed to remain open, mostly due to the depleted resources of the Federal Savings and Loan Insurance Corporation. Insolvent thrifts were not promptly closed and their assets sold to new investors. The policy of allowing insolvent institutions to remain open was labeled a policy of "forbearance" and Ed Kane deemed the insolvent thrifts "zombies". 2 Eventually, the Resolution Trust Corporation was established to liquidate the assets of insolvent thrifts. ${ }^{3}$ The bailout of the thrift industry ultimately cost $\$ 180$ billion (3.2\% of GDP); see Caprio and Klingebiel (1996). ${ }^{4}$

Prolonged and expensive government bailouts of financial intermediaries following banking crises have recently proliferated around the world, and it is not only transitional and emerging economies that have had such experiences. ${ }^{5}$ As in the U.S. thrift crisis, the resolution of these crises typically involves the use of public money to subsidize the restructuring or disposal of impaired loans, a "bailout." In a survey of 120 banks in 24 developed countries in the 1980s and 1990s, Goodhart (1995) found that two out of three failed banks were bailed out. These bailouts are expensive. In a sample of 40 such episodes, Honohan and Klingebiel (2000) found that, on average, countries spend 12.8 percent of their GDP cleaning up their banking

\footnotetext{
${ }^{1}$ For example, the assets of operating GAAP-insolvent institutions in 1984 were $\$ 107.3$ billion. The total assets of the 1,290 GAAP-insolvent institutions and nearly insolvent institutions were 45 percent of all assets of insured thrifts in 1984. See Brumbaugh (1988). On the thrift crisis generally see Barth (1991), Kane (1989), and White (1991).

2 The term "zombie thrifts" became widely used and is now applied to similar banking situations. In a private communication, Ed Kane recalls having first used this term in a speech to the American Bar Association in 1986. It first appeared in published work in Kane (1987), a paper that was presented at the Western Economics Association in 1986.

${ }^{3}$ The 1989 Financial Institutions Recovery, Reform and Enforcement Act (FIRREA) substantially changed the regulatory structure of the thrift industry. The Resolution Trust Corporation (RTC) was part of the 1989 law. The RTC was the government vehicle for selling the assets of closed thrifts.

${ }^{4}$ According to Barth and Bartholomew (1992), as of 1992: "More than 500 institutions were closed at an estimated present-value cost in excess of $\$ 50$ billion. Still another 500 or more institutions were open but insolvent at the end of the decade. These remaining candidates for closure will cost an estimated $\$ 100$ billion or more..." (p. 37). Other estimates are considerably higher. For example, the Wall Street journal, April 6, 1990, cites a Congressional Budget Office and General Accounting Office projection of a cost of $\$ 300$ to $\$ 350$ billion. See Kane and Yu (1996) for market value estimates.

${ }^{5}$ Caprio and Klingebiel (1999) count 112 episodes of systemic banking crises in 93 countries since the late 1970s. Since 1980, at least two-thirds of International Monetary Fund member countries have experienced problems with their banking systems (see Daniel (1997)). Also, see Lindgren, et. al., (1999).
} 
systems. Claessens, Djankov, and Klingebiel (1999) set the costs at 15-50 percent of GNP. To emphasize, even developed economies other than the U.S. have faced large costs of bank bailouts. For example, Spain is estimated to have spent 16.8 percent of GNP on bailouts, Sweden. 6.4 percent of GDP, Finland, 8 percent of GDP. See Caprio and Klingebiel (1996).

In bank bailouts the government directly aids banks by buying equity, extending longterm loan guarantees to the banks, or buying bank loans at favorable prices. (Usually, nonperforming loans are purchased by the government at face value (see Daniel (1997)).) Sometimes government bonds are exchanged for bad bank loans. Often a public centralized asset management company is set up that uses government funds to lend to troubled banks against specific loan collateral or that buys the loans from the banks. An early, and influential, example of such a vehicle was the Reconstruction Finance Corporation (RFC) that President Herbert Hoover initiated during the onset of the Great Depression in the U.S. (see Olson (1977)). The RFC is the (implicit or explicit) model for a large number of such vehicles in countries around the world, including the Resolution Trust Corporation, founded to use federal money to buy and then sell assets of insolvent U.S. savings and loans institutions (see Todd (1992)). As we discuss later, government bank restructuring agencies are now commonplace. ${ }^{6}$

Why do government bailouts occur? Why does the government engage in forbearance, rather than simply closing insolvent banks and selling their assets to private investors immediately? ${ }^{7}$ Are government bailouts efficient? The basic idea developed in this paper is that it is costly for private agents to be prepared to purchase the assets of the banking system (or a large part of the banking system) because liquidity is socially costly. Simply put, the sheer volume of the assets that need to be sold can be too large for private agents to absorb quickly. The resources of private agents are "illiquid." In order to make this point, we first must address the issue of "liquidity." What is "liquidity" and where does it come from? And, how does "liquidity" relate to "market efficiency"? The first part of the paper addresses these questions. The second part of the paper demonstrates how these answers are useful in understanding government bailouts. We show how the government can create liquidity and improve welfare. We go on to

\footnotetext{
${ }^{6}$ It is not only financial institutions that are bailed out. Nonfinancial firms are also sometimes bailed out. Nonfinancial firm bailout examples include firms that had outstanding commercial paper during the Penn Central crisis (see Calomiris (1994)), the Chrysler Corporation (see Iacoca and Novak (1986)), and the airlines industry following the terrorist attacks of September 11, 2001. In these cases, the government provided loan guarantees to a syndicate of banks and, in the case of Penn Central crises, provided liquidity through the Federal Reserve's discount window lending. A related example is the case of the hedge fund Long Term Capital Management (LTCM), where the lenders in effect purchased the assets at the government's instigation (see Lowenstein (2000)). LTCM is discussed further below.

${ }^{7}$ We do not address the issue of why banking systems come to be distressed. See Gorton and Winton (2002) for a survey of the literature on banking crises and banking panics.
} 
address the issue arise of whether the government has the resources to bailout the bank system. Perhaps a policy of "forbearance" is optimal. We provide conditions under which this is the case.

We start with a general setting in which agents who have invested in securities or projects sometimes need to sell them later. The price they fetch at that time depends upon the "liquidity" of the market. We present a general equilibrium model in which not all assets can be used to purchase all other assets at every date. "Liquid" assets are the only readily available funds that can be used to purchase projects/securities from other agents. "Liquidity" then refers to the extent to which liquidity supply can meet liquidity demand. If insufficient liquid funds are available, then claims on projects cannot be subsequently transferred, because potential new owners have no way to buy them. Projects that cannot be transferred may decline in value. Recognizing that there may be opportunities at future dates to buy, some agents initially choose to invest in "liquid" assets. So, liquidity provision can be socially efficient.

There are two requirements for a model of liquidity. First, there must be a need to trade: at some dates there must be agents seeking to sell assets and there must be other agents who are willing to buy. Second, there is a restriction needed, namely, not all assets can be used to purchase all other assets at every date. Buyers must be restricted to making purchases only with certain assets, "liquid" assets. This restriction is akin to a cash-in-advance constraint. The constraint arises from the fact that other assets are not liquid; they cannot be used to trade at some dates. In the model here agents make investment choices at the initial date, choosing a long-term investment project or choosing a short-term investment project. The only purpose of selecting a short-term project is to get "liquid" assets to possibly buy a troubled long-term project at a later date. Long-term projects are financed by borrowing from lenders. Subsequently, long-term project borrowers learn whether their projects are high value or low value. Owners of low value projects may engage in moral hazard. Low value projects may be recapitalized by being sold in the "liquidation" market to agents with available liquid capital. The only buyers available are agents who initially chose short-term projects for exactly this purpose.

It is costly for society to always have liquid funds stand by in large amounts, as alternative investments (long-term projects) are (socially) more attractive, but "illiquid." The private provision of liquidity can be avoided, if, instead of projects being sold in the liquidation market, the original lenders are willing to forgive debt of borrowers with low value projects. Such forgiveness dominates the private provision of liquidity since it does not involve inefficient "hoarding," i.e., investing in the short-term project to get liquid funds. But, forgiveness is not always in the interests of lenders. If forgiveness is not in their interests, then privately supplied liquidity is the only way to recapitalize projects. Since this is socially costly, perhaps the 
government can improve welfare by supplying liquidity. We show what it means for the government to supply liquidity.

Owners of long-term projects that had a high value realization are privately illiquid because they cannot monetize their gains, i.e., their assets are illiquid. But, the government can monetize their gains by issuing securities backed by tax revenue collected from these agents later. The government securities are used to subsidize owners of low value projects, while owners of high value projects are taxed later. Low value projects are recapitalized by the subsidies.

We then extend the analysis to consider possible systematic risk in the banking system and to investigate the phenomena of bank bailouts. As above, investment in projects at the initial date is financed through borrowing. Subsequently, long-term project owners learn the value of their projects and may desire to sell their projects in the liquidation market in order to obtain the recapitalization. But, the lending banks may also want to engage in moral hazard for the same reasons that their borrowers might engage in moral hazard. If banks suffer a negative shock to their capital (from other asset-side activities), then they may acquiesce in allowing their borrowers to engage in moral hazard rather than seeking to recapitalize them. In this case, banks are not interested in liquidating their borrowers' projects. Anticipating that this may occur affects the initial choice of investments, in particular the supply of liquidity, and can reduce social welfare. We provide conditions under which the government can improve welfare by bailing out banks.

There are many different notions of "liquidity" and "illiquidity" in the literature. ${ }^{8}$ In the finance literature, liquidity is not explicitly modeled. Rather there are "noise traders" or "liquidity traders," modeled as exogenous random amounts of buy and sell orders. The other side of the market is the "market maker" who has an inventory that potentially can be long or short an infinite amount (see Kyle (1985)). Because the market maker's inventory is infinite, the price set is equal to expected value of the payoff (conditional on available information). That is, the supply curve of liquidity is infinitely elastic so the price is not influenced by the size of the market maker's inventory. The model here obviously differs in important respects. Because the model is one of general equilibrium, the supply of liquidity will be determined endogenously and will not be infinitely elastic. Because we explicitly model liquidity provision we can conduct welfare analysis.

\footnotetext{
${ }^{8}$ Diamond and Dybvig (1983) view consumption smoothing as liquidity. Hopenhayn and Werner (1996) develop a notion of liquidity based on search. In Gorton and Pennacchi (1990) liquid assets are assets that minimize trading losses to uninformed traders when they trade in markets with privately informed traders. "Liquid assets" are not sensitive to private information because they are relatively riskless, like bank deposits.
} 
In other papers, "liquidation" of projects is modeled in partial equilibrium as an exogenous value, interpreted as the value of the project in its next best alternative use. In reality, the next best alternative use is the value of the project to another agent, so the "liquidation value" of a project depends on the price that the project fetches in the market when it is sold to the other agent. And that price, in turn, depends on the supply of liquidity, that is, on the aggregate resources of those agents who can feasibly bid at that date. Shleifer and Vishny (1992) make the point that when a distressed firm needs to sell assets, the natural buyers are other firms in the same industry. The other firms may also be distressed, leading to the conclusion that the price of the assets being liquidated is partly a function of the available supply of liquidity, not just information about payoffs. We formalize this by showing how it can occur that liquidity is not in perfectly elastic supply; in that case, a project's "fundamental value" may be different from the price it trades for in the market, a price that depends upon the amount of liquidity available, or the market "depth." Thus, the notion of "market efficiency," i.e., the idea that prices are conditional expectations of project payoffs, requires perfectly liquid markets. Otherwise, markets are not price efficient, but there is no arbitrage possible because of the lack of liquid assets to conduct such a trade. We provide a model of this.

Our model is also related to Holmström and Tirole (1998). In their model, firms need to hoard resources internally for possible future investment. Agency problems prevent them from using privately created securities; only government securities will do. Both models study the liquidity problem caused by the agency problem and market incompleteness. In their model, firms are identical and so there is no secondary liquidation market for real assets. Like Holmström and Tirole (1998) we do not allow full insurance markets. Unlike them, we endogenize the supply of liquidity by allowing entrepreneurs to choose whether to be either buyers or sellers in the secondary market. Our focus enables us to extend the analysis to banking crises and bank bailouts. Since the model is one of general equilibrium, we can conduct welfare analysis.

Diamond and Rajan (2001) develop a model of bank production of liquidity, with implications for government bailouts of banks. In a setting where borrowers cannot commit to use their human capital on behalf of lenders, banks can arrange a capital structure that commits them to collect the maximum amount from borrowers (more than individual lenders could collect because banks have superior skills in this regard). The idea is that the borrowers' human capital becomes "liquid," even as the banks' loans become illiquid. If the maturity profiles of the loans are different for different banks, and banks can only raise money against a fraction of the payments on longer maturity projects, then at interim dates bank runs may result in varying amounts of projects being liquidated, depending on the maturity profile of the loans. It may happen that this causes otherwise solvent banks to become insolvent, creating a role for the 
government to recapitalize banks. See Diamond and Rajan (2002) and Diamond (2001). As will become apparent, the notion of liquidity here is quite different, as is our general equilibrium focus on the supply of liquidity. ${ }^{9}$

The notion of liquidity we develop is intuitive. It refers to the amount of resources standing ready to purchase the projects should there be a desire to sell the projects at some date between initiation and final payoff. As in Grossman (1988), some agents must commit at the initial date to have certain resources available at an interim date, should opportunities arise. We provide a model of this "liquidity-in-advance" constraint.

The paper proceeds as follows. In Section II the model is presented and the assumptions discussed. In Section III we show that there is no need for liquidity, in the sense of agents standing ready to buy projects, if lenders are willing to forgive the debt of distressed borrowers. Debt forgiveness is a kind of liquidity provision on the part of the lender, and it can implement the First Best allocation. If debt forgiveness is not optimal for lenders, then there is a need for private agents to provide liquidity. This is studied in Section IV. The equilibrium in which liquidity is provided privately is analyzed. This allocation is not First Best, but the government via bailouts may be able to improve welfare and achieve First Best. A system of taxing and subsidizing amounts to liquidity creation, and we provide a condition under which First Best can be achieved. It is studied in Section V. Section VI considers the extended case where bank lenders themselves may seek to engage in moral hazard, by acquiescing in allowing their distressed borrowers to engage in moral hazard. This results in an even less efficient outcome. However, under certain conditions, a government bailout can achieve First Best. Section VII concludes.

\section{The Model}

In this section we present the model and discuss the important assumptions.

There is a continuum of depositors, a continuum of entrepreneurs and a continuum of banks in the economy. There are three dates: 0,1 , and 2 . At date 0 entrepreneurs must choose one of two possible investment projects, either a long-term project or a short-term project. The long-term project requires an investment of $\$ 1.00$ at date 0 . The short-term project only needs the entrepreneurs' human capital. The cash flow of the long-term project is realized at date 2 . It can be high (H) with probability $\pi$ or low $(\mathrm{L})$ with probability $1-\pi$. Information about the date 2 cash flow arrives at date 1 . The cash flow of the short-term project is realized at date 1 , which is a random variable equal to $r$, where $r$ is uniformly distributed on the interval $[0, R]$. For simplicity,

\footnotetext{
${ }^{9}$ Eisfeldt (2002) presents a general equilibrium model of liquidity based on adverse selection. Agents are motivated to trade by changes in productivity and this interacts with desires to self-insure.
} 
there is no available short-term project between dates 1 and 2 . We make the following assumptions on cash flows from the projects, operation of the projects and how the projects can be financed.

A1: $\pi \mathrm{H}+(1-\pi) \mathrm{L}>1+\mathrm{R} / 2$. That is, the long-term project has a higher expected cash flow than the short-term project.

Because the long-term project offers superior returns, we refer to investing in the shortterm project as "hoarding." As we will see, the only reason any entrepreneur will invest in the short-term project is that it enables him to purchase a long-term project in the low state at date 1.

A2: Each entrepreneur can only manage one project at a time. Projects are not divisible.

A3: Neither the date 1 states ( $\mathrm{H}$ or $\mathrm{L}$ ), nor the cash flows realized at date 2, are contractible. Therefore, outside equity financing is not feasible.

Entrepreneurs have no resources at date 0, so they need to borrow from banks. The credit market is competitive at date 0 . Therefore, entrepreneurs receive the entire expected surplus and lenders earn zero expected profits. For simplicity, all agents are risk neutral and the riskless interest rate is zero.

At date 0 investment decisions are taken and entrepreneurs who choose long-term projects borrow from the lenders. Because states and cash flows are not verifiable, we only allow debt contracts, which can be viewed as a reduced form of costly state verification models, as in Townsend (1979). At date 1 entrepreneurs operating short-term projects receive the realization of the projects' cash flows. Entrepreneurs operating the long-term project receive no cash flows at date 1 , but they learn the realization of the state, $\mathrm{H}$ or $\mathrm{L}$. This information is also observable by the lenders, but by A3 it is not contractible. Other agents, in particular the government, do not observe the realized project states at date 1 .

Denote by $\alpha$ the fraction of entrepreneurs that take the long-term project at date 0 ; the fraction of the entrepreneurs that take the short-term project at date 0 is 1- $\alpha$. After each entrepreneur chooses a project type, those choosing the long-term project sign a debt contract with one of the lenders. The face value of the debt contract, F, will be determined in equilibrium.

There is a potential moral hazard problem because the entrepreneurs may engage in asset substitution at date 1. Each entrepreneur, regardless of which project has been selected at date 0 , has access to a constant returns to scale risk-adding technology. By adding risk, one unit of 
certain value generates either a very large value, T, with probability $\delta$ or a value of zero with probability $1-\delta$.

A4: $\delta \mathrm{T}<1$. That is, adding risk to the project is inefficient. $1-\delta \mathrm{T}$ is the expected loss per unit from asset substitution.

Suppose an entrepreneur owes an amount $f$ and he learns that his cash flow at date 2 will be $\mathrm{v}$. If he does not add risk, his payoff is: $\max [\mathrm{v}-\mathrm{f}, 0]$. If he adds risk, his expected payoff is: $\max [\delta(v T-f), 0]$. Suppose vT is greater than $f$. The entrepreneur is not going to add risk if and only if $\delta(v T-f) \leq v-f$. That is, the face value of the debt, f, cannot exceed $\gamma_{\mathrm{v}}$, where $\gamma \equiv \frac{1-\delta T}{1-\delta}$.

A5: $\gamma \mathrm{L}<1$. Since the debt face value is at least $\$ 1$, this assumption says that in the low state, the cash flow to the long-term project is not large enough to prevent entrepreneurs from adding risk. Thus, there is a moral hazard problem at date 1 .

Although entrepreneurs may have incentives to engage in moral hazard at date 1, ex ante they want to prevent it because they get the entire expected surplus and bear the entire potential loss caused by risk-adding. There are two possible ways to prevent the moral hazard problem. First, the contract between the lender and an entrepreneur can be renegotiated at date 1 to remove the entrepreneur's incentive to engage in asset substitution. In particular, the lender can forgive some of the debt, by lowering the face value of the (pure discount) debt, and thus increase the entrepreneur's equity to eliminate his incentive to add risk. But this depends on whether the lender is willing to forgive debt. It can happen that the lender finds forgiveness unprofitable and renegotiation breaks down.

Secondly, the project may be "liquidated." "Liquidation" means that the "troubled" project, i.e., the project of an entrepreneur who will otherwise add risk, is sold to a new owner at date 1. It is better to sell the troubled project if the liquidation value is higher than the continuation value of the project with risk being added. On the other hand, selling the project to a new owner means that the assets are redeployed, but does not necessarily mean that the new owner will add no risk. If the new owner has to borrow at date 1 to buy the project, then the lender will have to ensure that the new owner has enough equity in the project so that they do not have an incentive to add risk upon buying the project. 
A central question is: Who will buy troubled projects at date 1? Because each entrepreneur can only manage one project at a time, buyers of projects at date 1 can only be entrepreneurs who undertook the short-term project at date 0 . We will call them "liquidity suppliers" since it is the availability of their resources at date 1 that can allow project ownership to be transferred. Clearly, the price at which a troubled project can be sold at date 1 will depend on the demand and supply of liquidity and this price will be determined in equilibrium. In addition to the assumptions we have made, we make the following assumptions about the cash flows from the long and short-term projects to make our model more interesting.

A6: TL $>\gamma \mathrm{H}$. That is, if an entrepreneur engaging in moral hazard is lucky, there is a chance that risk-adding can produce a cash flow high enough that his equity value is positive after repaying the face value of the debt.

A7: $(\pi+\delta(1-\pi)) \gamma H \geq 1$. Due to the possible moral hazard problem, the face value of the debt cannot exceed $\gamma H$. Otherwise entrepreneurs will add risk even in the high state. This assumption guarantees that the cash flow in the high state is large enough that the bank is willing to lend at date 1 , even though entrepreneurs might engage in risk-adding when they are in the low state.

A8: $\delta \mathrm{T}>\gamma$. This assumption is equivalent to $\delta \mathrm{TL}>\gamma \mathrm{L}$. $\delta \mathrm{TL}$ is the expected date 1 value of a longterm project in the low state when risk has been added. $\gamma \mathrm{L}$ is the maximum of the face value that a bank can charge (possibly after forgiveness) such that the entrepreneur has no incentive to add risk. By assuming $\delta \mathrm{TL}>\gamma \mathrm{L}$, we make it possible that forgiveness is not in the interests of the lenders.

A9: $\mathrm{R}>\mathrm{L}-\gamma \mathrm{TL} . \mathrm{R}$ is the maximum payoff from the short-term project. This assumption implies that if there is an excess supply of liquidity, the liquidation price can be as large as the "fundamental" value of the asset. This will become clear when we analyze the liquidation market in Section IV.

To summarize, the sequence of events at date 1 is as follows.

An entrepreneur who invested in the short-term project at date 0 receives a cash flow of $r$ at date 1. 
(ii) News arrives about whether the date 2 cash flow of each long-term project will be high $(\mathrm{H})$ or low $(\mathrm{L})$.

(iii) Owners of troubled long-term projects renegotiate with their lenders to try to reduce their debt burden.

(iv) Depending on the outcome of the renegotiation, an entrepreneur may "liquidate" his project, i.e., sell it in the market, or he may continue until date 2 (possibly adding risk) to receive the final cash flow. If the project is sold in the liquidation market, then the new owner operates the project (possibly adding risk), and receives the final cash flow at date 2 .

(v) If the project is liquidated, then a final payment (that was previously renegotiated) is made (at date 1 or possibly at date 2 ) to the lender to settle the outstanding loan. The new owner then operates the project.

At date 2, the cash flows of the long-term projects are realized and lenders are repaid.

By A1, the First Best outcome would be for all the entrepreneurs to invest in the longterm project. But, because of the moral hazard problem, this may not be the outcome of private decisions. Some entrepreneurs may choose to invest in the short-term project, in order to act as liquidity providers at date 1 . The date 1 opportunity may be sufficiently valuable to make "hoarding" at date 0 attractive.

\section{B. Discussion of Assumptions}

There is an essential incompleteness in markets, which can cause some entrepreneurs to invest in the short-term project at date 0 , in order to be liquidity providers at date 1 . There is no way to insure the long-term projects against the low outcome because states and cash flows are not verifiable. Only the entrepreneurs with enough equity at date 1 can buy a troubled long-term project. Note that some entrepreneurs who chose the long-term project at date 0 receive good news at date 1 so they have projects worth $\mathrm{H}$. In other words, at date 1 they have a capital gain relative to the expected value of the project as of date 0 . Under the above assumptions, if their equity is high enough, they could issue subordinated debt to buy another troubled project. But, since projects are indivisible, their equity value has to be high enough to buy an entire firm. Whether this can happen or not depends on parameter values. For simplicity, we just assume that their limited human capital only allows them to manage one project at a time. ${ }^{10}$ Alternatively, the

\footnotetext{
${ }^{10}$ Alternatively, one can imagine more complicated explanations for why entrepreneurs who have realized $\mathrm{H}$ cannot credibly issue securities to buy projects at date 1, e.g., asymmetric information could be introduced.
} 
long-term projects of different borrowers can be interpreted to be different (say, different industries), and entrepreneurs in the high state in one industry do not have the expertise to manage the projects in the low state, implicitly in another industry. ${ }^{11}$

There are several interpretations of the random cash flow return to the short-term project, $\mathrm{r}$, realized at date 1. A straightforward interpretation is that the short-term projects literally are a technology with some uncertainty. Alternatively, one can think of the short-term projects as producing $\mathrm{R}$, but entrepreneurs have a random consumption need or production cost uniformly distributed in $[0, R]$ which is subtracted from $R$, leaving $r$.

A model of liquidity needs a motive for some agents to sell assets. Here moral hazard provides the motivation for selling projects at date 1. But, other motivations would suffice as well. For example, random preferences over the timing of consumption could cause some agents to want to sell their projects at date 1 . The specific motivation of moral hazard is, however, important in Section VI, when we consider the banking system.

Another issue concerns the shocks to the long-term projects. They are idiosyncratic and independent of the random payoffs to the short-term projects. However, we could have systematic shocks and idiosyncratic shocks, plus correlation between the cash flows from the long-term and short-term projects without changing the main results. For simplicity, we do not include systematic shocks and correlation in the model.

\section{Debt Forgiveness}

To avoid the moral hazard problem, borrowers need an equity injection at date 1 if their projects are in the low state. If the project is sold in the liquidation market, then a new owner injects equity. But, the lender is an alternative source of equity, in the sense that debt forgiveness creates equity for the original owner. To begin the analysis, we analyze the case where equity is injected via the lender forgiving some of the debt. In this case, all entrepreneurs will invest in the long-term project at date 0 , which is the First Best outcome, as there is no need for private liquidity provision at date 1 . Investment in the short-term project is dominated.

We start by solving for the subgame equilibrium at date 1 . At date 1 , if a long-term project is in the high state, then nothing happens (by A7, there exists a face value of the debt, F, such that an entrepreneur has no incentive to add risk in the high state.) However, if a long-term project is in the low state, $\mathrm{L}$, then the project is worth $\mathrm{L}$ if no risk as added and is worth $\delta \mathrm{TL}$ if

\footnotetext{
${ }^{11}$ Holmström and Tirole (1998) have a similar assumption. Lucky firms (with additional liquidity) are not allowed to take over unlucky firms (short of liquidity). In Diamond and Rajan (2002) banks find out at an interim date whether their loan maturities are long or short; banks cannot insure against the risk of having a long maturity portfolio realization at this date.
} 
risk is added. By A5 borrowers will add risk if they retain ownership of the project without any new equity.

Renegotiation between the borrower and the lender has three possible outcomes. First, the original owner may continue until date 2 without adding risk if the lender forgives some debt. Second, the project may be sold or liquidated, in which case the original owner receives the price $\mathrm{Q}$ (the liquidation value). However, this entrepreneur owes the lender F, which must be paid at date 1 if the debt is short-term or at date 2 if the debt is long term. Renegotiation must allocate $Q$ between the borrower and the lender. Finally, the project may remain in the original owner's hands with risk being added. Equilibrium at date 1 involves determining which of these outcomes is the result of renegotiation between borrowers and lenders.

In order for the first possibility to occur, the lender must forgive part of the debt. This is an equity injection, a subsidy granted to the entrepreneur by the lender, to induce the entrepreneur not to add risk. By the analysis above (just before A5), the lender must agree to lower the face value of the debt to $\gamma \mathrm{L}$ to remove the entrepreneur's incentive to add risk. The lender is willing to forgive debt, that is, reduce the face value from $F$ to $\gamma \mathrm{L}$, if and only if $\gamma \mathrm{L}$ is greater than $\delta \mathrm{F}$, the expected payoff to the lender when risk will be added. The following lemma provides the condition under which debt forgiveness is feasible.

Lemma 1: Debt forgiveness is feasible if and only if $\chi \geq \frac{\delta}{\pi+\delta(1-\pi)}$.

Proof: See Appendix.

If debt forgiveness is feasible, then there will be no need for liquidity provision at date $1^{12}$ Since, ex ante, the long-term project is more efficient than the short-term project, no entrepreneur will choose the short-term project at date 0 ; all entrepreneurs will choose the longterm project. Lenders only receive the face value of the debt, $\mathrm{F}$, in the high state, which happens with probability $\pi$. In order to make lenders break even, $F$ has to satisfy the following condition: $\pi F+(1-\pi) \gamma L \geq 1$, or $F \geq \frac{1-(1-\pi) \mathcal{L}}{\pi}$. Proposition 1 summarizes the above analysis:

\footnotetext{
${ }^{12}$ Later we will show that the liquidation price cannot exceed L. Therefore, the entrepreneurs who choose the long-term project at date 0 also choose debt contracts under which renegotiation brings out forgiveness.
} 
Proposition 1: If $\chi \geq \frac{\delta}{\pi+\delta(1-\pi)}$, then all entrepreneurs choose the long-term project at date 0. The face value of the debt is $\frac{1-(1-\pi) \varkappa}{\pi}$. This is the First Best outcome.

The proposition says that as long as debt forgiveness at date 1 is feasible, it will occur. The details of the division of the surplus between the lender and the borrower do not matter. Whatever the division, based on relative bargaining power, the equilibrium will be the same, as the entrepreneurs price this in getting the entire expected surplus at date 0 .

Debt forgiveness by the lender is a kind of liquidity provision because the lender is essentially refinancing the project, taking into account the new information, namely the state $L$, and the problem of moral hazard. ${ }^{13}$ Liquidity provision is an important function of banks. ${ }^{14}$ If forgiveness by the lender is feasible, then there is no need for a secondary market to refinance the project (by selling it to another party). Proposition 1 allows us to identify the condition under which the provision of liquidity (by agents other than the lenders, i.e., by entrepreneurs who hoard liquid assets) is socially valuable. According to the proposition, debt forgiveness solves the moral hazard problem, and there is no need for liquidity provision, so long as $\gamma L \geq \frac{\delta}{\pi+\delta(1-\pi)}$.

If this is not the case, then there is a need for the liquidation market. Ex ante, the owners of longterm projects get a surplus if the liquidation price prevailing in the secondary market is higher than the value of project with risk being added. The liquidity suppliers gain a profit if the liquidation price is less than the value of the project free from added risk. At date 0 entrepreneurs make project choices and at the same time choose to be liquidity demanders or liquidity suppliers. At date 1, a secondary market will arise endogenously. This is analyzed in the next section with the assumption that $\chi \leq \frac{\delta}{\pi+\delta(1-\pi)}$, i.e., debt forgiveness is not feasible.

\section{The Market for Liquidity}

If lenders are unwilling to forgive debt, then equity will have to be created in some other way as a solution to the moral hazard problem. The alternative is to sell the project to another,

13 The case of the hedge fund Long Term Capital Management (LTCM) is a recent example of forgiveness by lenders (see Lowenstein (2000)).

${ }^{14}$ The empirical results of Lummer and McConnell (1989) suggest the positive announcement effect associated with bank loans is due to loan renewals, rather than the initial loan, consistent with bank debt forgiveness being important. See Gorton and Winton (2002) for a survey of the related literature. 
better capitalized, entrepreneur at date 1 . We refer to this secondary market as the "liquidation market." In other words, at date 1 there is a market in which owners of long-term projects can sell their projects to other entrepreneurs with available resources to purchase the project.

\section{A. Preliminaries}

Because we are assuming that debt forgiveness is not feasible, the project can either be liquidated at price $\mathrm{Q}$, or can be continued with risk being added, in which case it has an expected cash flow of $\delta \mathrm{TL}$. Actually, whether the project will be liquidated only depends on the liquidation price Q. It does not depend on the maturity of debt contracts and the assignment of bargaining power when renegotiation occurs at date 1 . So long as $\mathrm{Q}$ is greater than $\delta \mathrm{TL}$, the lender and the borrower can always reach an agreement to liquidate the project and split the surplus. For simplicity, we assume that the debt contracts are long-term and the borrower has all the bargaining power. When renegotiation occurs at date 1, he makes a take-it-or-leave-it offer to the lender. The lender gets $\delta \mathrm{F}$ (the lender's expected payoff if the project continues with risk being added) and he gets $\mathrm{Q}-\delta \mathrm{F}$.

\section{B. The Liquidation Market and Liquidation Prices}

Potential liquidity suppliers at date 1 are those entrepreneurs who invested in the shortterm project at date 0 . At date 1 , each of them has realized a cash flow of $r$, drawn from a uniform distribution on $[0, \mathrm{R}]$. If $\mathrm{r}$ is small, then the entrepreneur will not have enough to afford the liquidation price. Therefore, some of the entrepreneurs may have to borrow in order to buy a troubled project. Buyers themselves also face the moral hazard problem since they too have access to the risk-adding technology. Although the realized $r$ is not publicly observable, we assume that if a project buyer borrows from a lender to buy a project, how the loan is used is verifiable. In other words, the amount borrowed can only be used to buy the project. In this way, if a buyer borrows $\mathrm{B}$ and buys a project at price $\mathrm{Q}$, the lender knows the borrower's realized $r$ is

at least Q-B. Therefore, it can be determined whether potential buyers have incentives to add risk to the project and whether the loan to the buyer is safe.

A buyer has no incentive to add risk if and only if the face value of the debt B is small enough such that $\mathrm{L}-\mathrm{B} \geq \delta$ (TL-B), i.e., $\mathrm{B} \leq \gamma \mathrm{L}$. Therefore, the buyers who have a realized $\mathrm{r} \geq \mathrm{Q}-\gamma \mathrm{L}$ are not going to engage in moral hazard and the loans lent to them are safe. Other buyers do not have enough equity and have incentives to add risk once they get the control of the projects.

Because of the buyers' potential moral hazard problems, not every entrepreneur who hoarded liquid assets can be a liquidity supplier. Liquidity supply at date 1 depends on the buyers' ability to buy. "Ability" means how much equity they have, that is, the size of the 
realized return from their short-term project. The next lemma characterizes their ability to supply liquidity at a given price.

Lemma 2: Suppose the liquidation price of a project is $Q$. Then:

(i) If $Q>L$, then there will be no liquidity supply in the liquidation market.

(ii) If $\delta T L<Q \leq L$, then only those buyers with realized cash flows $r \geq Q-\gamma$ are able to supply liquidity.

(iii) If $Q<\delta T L$, then all buyers can be liquidity suppliers.

Proof: See Appendix.

We know that a troubled project is liquidated if and only if the liquidation price $\mathrm{Q}$ is greater than or equal to $\delta \mathrm{TL}$. So, the liquidity demand curve (or the project supply curve) is perfectly elastic at price $\delta \mathrm{TL}$. By Lemma 3, we know that no entrepreneur is willing to pay more than $\mathrm{L}$ to buy a project. Moreover, as the liquidation price declines from $\mathrm{L}$ to $\delta \mathrm{TL}$, more and more entrepreneurs are willing to buy the projects. Thus, there is a downward-sloped liquidity supply curve (or a downward-sloped project demand curve). Combining liquidity demand with liquidity supply determines the liquidation price in the secondary market, which depends on the fraction of entrepreneurs taking the long-term project at date 0 .

Lemma 3: At date 1, the price in the liquidation market, $Q$, will be:

$$
\begin{array}{ll}
Q=\delta T L & \text { if }(1-\alpha)\left(1-\frac{\delta T L-\gamma L}{R}\right) \leq \alpha(1-\pi) \\
Q=\gamma L+R\left(1-\frac{\alpha(1-\pi)}{1-\alpha}\right) & \text { if }(1-\alpha)\left(1-\frac{L-\gamma L}{R}\right)<\alpha(1-\pi)<(1-\alpha)\left(1-\frac{\delta L T-\gamma L}{R}\right) \\
Q=L & \text { if } \alpha(1-\pi) \leq(1-\alpha)\left(1-\frac{L-\gamma}{R}\right) .
\end{array}
$$

Proof: See Appendix.

We define the "liquidity discount" to be the difference between the "fundamental" value of the project, namely L, and the liquidation price Q. Lemma 4 shows that a liquidity discount can arise in equilibrium. That is, the equilibrium price in the liquidation market, $\mathrm{Q}$, can be below the value of the project if risk is not added, $L$. This discount is necessary to entice liquidity suppliers to invest in the short-term project in order to buy the projects. 
To emphasize that the market price of the equity sold in the liquidation market has a price that depends on liquidity, we further examine the relationship between the price and the supply of liquidity with some figures. Figures 1, 2, and 3 show the secondary market equilibrium with respect to different levels of $\alpha$, the fraction of entrepreneurs taking the long-term project. (So, $1-\alpha$ is the fraction that has chosen short-term projects in order to later be liquidity suppliers.) When $\alpha$ is very small, liquidity demand is small while liquidity supply is large, and the liquidation price is at its maximum L. In this case, the liquidity discount is equal to zero (see Figure 1). When $\alpha$ is very large, liquidity demand is large while liquidity supply is small, and the liquidation price is at its minimum $\delta \mathrm{TL}$. The liquidity discount is at its maximum $\mathrm{L}-\delta \mathrm{TL}=\mathrm{L}(1-\delta \mathrm{T})$ (see Figure 3). When $\alpha$ is in the medium range, there is an interior equilibrium liquidation price, Q, at which all the liquidity demand can be satisfied while liquidity supply is downward sloped (see Figure 2). In this case the liquidity discount is between zero and L(1- $\delta \mathrm{T})$.

In the liquidation market, ownership claims, i.e., equity claims, to the project are sold and a new entrepreneur acquires control rights. The new entrepreneur has the right to choose whether to add risk or not. In equilibrium no risk is added. In the finance literature, when "market efficiency" is mentioned, the transfer of control rights, which usually results in a change of the asset value, is typically not considered. Moreover, the supply of liquidity is perfectly elastic. Here, due to the moral hazard problem and the limited liquidity supply, the notion of "market efficiency" is altered. Although, in equilibrium, risk will not be added and the continuation value of the project is L, there is a liquidity discount. Ex post, the liquidity discount reflects insufficient liquid assets in the market. Ex ante, the liquidity discount is necessary to compensate the liquidity suppliers because there is a cost associated with supplying liquidity. We next solve the entrepreneur's date 0 decision problem.

\section{Initial Investment Choices}

At date 0 , entrepreneurs have rational expectations about how the liquidation price is formed in the secondary or liquidation market of date 1. An entrepreneur makes his project choice, taking other entrepreneurs' choices as given. We solve for the date 0 equilibrium in the following proposition (under the maintained assumption that debt forgiveness is not feasible at date 1).

Proposition 2: Suppose that $\chi<\frac{\delta}{\pi+\delta(1-\pi)}$, i.e., debt forgiveness is not feasible at date 1 . Then: 
If $\pi H+(1-\pi) \delta T L>1+\frac{R}{2}+(L-\delta T L)\left(1-\frac{\delta T L-\gamma}{R}\right)$, then all the entrepreneurs choose the long-term project at date 0. In this case, there will be no liquidity supplied at date 1, and risk will be added to all projects realizing the low state at date 1 .

If $\pi H+(1-\pi) \delta T L \leq 1+\frac{R}{2}+(L-\delta T L)\left(1-\frac{\delta T L-\gamma}{R}\right)$, then there is a fraction $\alpha^{*} \in(0$, 1) of entrepreneurs who choose the long-term project at date 0, and a fraction (1- $\left.\alpha^{*}\right)$ of entrepreneurs who choose the short-term project at date 0 . $\alpha^{*}=\frac{\mathrm{R}+\gamma \mathrm{L}-\mathrm{Q}^{*}}{(2-\pi) \mathrm{R}+\gamma \mathrm{L}-\mathrm{Q}^{*}}$, where $\mathrm{Q}^{*}=\frac{(2-\pi) \mathrm{R}+(1+\gamma) \mathrm{L}-\sqrt{((2-\pi) \mathrm{R}+(1+\gamma) \mathrm{L})^{2}-4\left(\mathrm{R}\left(1+\frac{\mathrm{R}}{2}-\pi \mathrm{H}+\mathrm{L}\right)+\gamma \mathrm{L}^{2}\right)}}{2}$ $\in[\delta T L, L]$ is the liquidation price at date 1 .

Proof: See Appendix.

Proposition 2 relates the primitives of the economy to the incidence of liquidation. Entrepreneurs compare the expected payoffs on the two projects available to them at date 0 , taking into account the possible transactions in the liquidation market. The short-term project has a return of $\mathrm{r}$ over the first period and a return over the second period that depends on the profitability of buying a distressed project at date 1 and operating it until date 2 . If these returns are too low, compared to the long-term project (when risk is added in case $\mathrm{L}$ is realized), then all entrepreneurs will still take the long-term project. Otherwise there is an active secondary market and some entrepreneurs engage in each activity. In that case, supplying liquidity is both privately profitable and socially efficient.

\section{Comparative Statics}

Proposition 2 provides the solution to the initial general equilibrium investment problem. In equilibrium, entrepreneurs are indifferent between investing in the long-term project or in the short-term project at date 0; they get the same expected payoff ex ante. By assumption, entrepreneurs get the entire expected surplus, thus their expected payoff is a measure of social welfare. The expected payoff to entrepreneurs who take the long-term project is $\pi H+(1-\pi) Q^{*}$, and the expected payoff to entrepreneurs who take the short-term project is 
$1+\frac{\mathrm{R}}{2}+\left(\mathrm{L}-\mathrm{Q}^{*}\right)\left(1-\frac{\mathrm{Q}^{*}-\gamma \mathrm{L}}{\mathrm{R}}\right)$. Social welfare, the liquidation price, $\mathrm{Q}^{*}$, and thus the liquidity discount, L-Q*, all depend on the parameter values: $\pi, \mathrm{R}$ and $\delta . \pi$ measures the quality of the long-term project; R measures the quality of the short-term project; and $\delta$ measures the severity of the moral hazard problem. Proposition 3 and Corollary 1 show the comparative statics:

Proposition 3: Social welfare is increasing in $\pi$ and $R$, and decreasing in $\delta$.

Corollary 1: The liquidation price $Q^{*}$ (the liquidity discount, $L-Q^{*}$ ) is increasing (decreasing) in $R$ and decreasing (increasing) in $\pi$ and $\delta$.

Proof: See Appendix.

$\mathrm{L}-\mathrm{Q}$ * is the equilibrium liquidity discount, which is a measure of how profitable it is to hoard assets by investing in the short-term project. It is also the necessary compensation a liquidity provider requires to sacrifice the long-term project. The larger the difference between the expected payoff from a long-term project (in the absence of the moral hazard problem) and that from a short-term project, the higher liquidity discount is required. When $\delta$ increases, $\gamma$ increases, and thus the threshold to be a liquidity supplier is increased. The liquidity discount has to be lowered to compensate the decrease in probability to be a liquidity supplier (a lower $\mathrm{Q}^{*}$ ). A larger $\pi$ increases the expected payoff of the long-term project and decreases the liquidity demand, thereby resulting in a higher liquidity discount (a lower $\mathrm{Q}^{*}$ ). On the other hand, a higher $\mathrm{R}$ increases the expected payoff of the short-term project and therefore results a lower liquidity discount (a higher $\mathrm{Q}^{*}$ ).

The effects of $\mathrm{R}, \pi$ and $\delta$ on welfare are quite intuitive. When $\mathrm{R}$ and $\pi$ increases, the overall investment quality in the economy is improved. Hence, welfare increases. On the other hand, when $\delta$ increases, the moral hazard problem is mitigated and therefore welfare increases.

\section{E. Summary}

Entrepreneurs cannot buy insurance at date 0 against declines in the value of their equity at date 1 . Nor can entrepreneurs with high value projects at date 1 use that value to inject equity into the low value projects. These markets do not exist and as a result of these missing markets, private liquidity provision can be efficient. The existence of a liquidity discount is a measure of the shadow price of the liquidity-in-advance constraint. To the extent that this constraint binds, 
the market price of project equity at date 1 reflects this constraint, not just the expected payoff on the project.

However, the government may be able to improve upon the private allocation because hoarding by investing in the short-term project is dominated by investment in the long-term project. We now analyze the role of the government.

\section{Government Bailouts}

Because of the moral hazard problem, the First Best outcome cannot be reached in the equilibrium studied above. The private supply of liquidity is inefficient since some investments are made in short-term projects, which are ex ante dominated by long-term projects. Can the government improve the efficiency of the economy? If the entrepreneurs had enough capital at date 0 , then there would be no need for them to borrow, and the First Best outcome could be reached. Suppose the lenders are banks. ${ }^{15}$ If the government has the power to tax bank depositors and subsidize the entrepreneurs at date 0 then they would have enough equity to avoid borrowing and the moral hazard problem would never arise. But, such transfers require that date 0 endowments be verifiable. In our model, entrepreneurs get the entire surplus. Depositors will not save their endowments in the bank if they anticipate the government is going to tax their savings. Therefore the subsidies have to be financed via taxing entrepreneurs in high states.

If the government can tax entrepreneurs with high returns and subsidize entrepreneurs with low returns, the government can at least partially improve efficiency by eliminating the incentives to add risk from some of the entrepreneurs in the low state. Unfortunately, the states of the long-term projects are only observable by banks and entrepreneurs and they are not verifiable. If the government cannot observe the states of projects at date 1 , it has to design a screening mechanism to find which entrepreneurs are in the high state and which entrepreneurs are in the low state. We will show that the government can screen the banks by offering to buy the loans. In this section we examine such government bailouts.

\section{A. Government Liquidity Provision}

The government bailout mechanism works as follows. At date 1, the government offers to buy loans from banks. Each bank can either sell its loans to the government at a specified price $\mathrm{P}$, or pay a tax, $\mathrm{t}$, at date 2 if it does not sell its loans to the government at date 1 . Once the government holds the loans, it can forgive part of liabilities of the troubled projects to remove the entrepreneurs' incentives to engage in moral hazard

\footnotetext{
${ }^{15}$ At this point, we assume lenders are banks, to foreshadow the analysis of bank bailouts in Section VII.
} 
Alternatively, the government can offer subsidies to the banks (e.g., loan guarantees). To receive the subsidy, the bank has to lower the face value of the loan. In equilibrium, only the banks with troubled loans will accept the offer from the government. In this way, the government can distinguish the high projects from the low projects and make transfers to improve efficiency. Whether government intervention can generate the First Best outcome depends on how much tax revenue it can collect from projects in the high state. The government certainly does not want the high projects to suffer from moral hazard problems and thus have to guarantee that the owners of high projects pay less than $\gamma \mathrm{H}$ at date 2 (i.e., the face value of the debt cannot exceed $\gamma \mathrm{H}$ ). If government intervention alone cannot generate the First Best outcome, maybe there is still a need for private liquidity to be supplied at date 1 .

Proposition 4: If $\gamma(\pi H+(1-\pi) L) \geq 1$, then a government bailout can generate the First Best outcome as of date 0. At date 0 , entrepreneurs and banks sign debt contracts with a face value of $F=\frac{1-(1-\pi) \chi}{\pi}$. At date 1 , the government offers to buy the loan at price $P=\frac{\delta}{\pi+\delta(1-\pi)}$. Banks with troubled projects sell their loans to the government and banks with high state projects retain their loans and pay a tax of $t=\frac{1-(1-\pi) \gamma L}{\pi}-\frac{1}{\pi+\delta(1-\pi)}$ at date 2 .

Proof: See Appendix.

If $\gamma(\pi \mathrm{H}+(1-\pi) \mathrm{L})<1$, then government intervention cannot produce the First Best outcome because the government cannot levy enough taxes on the entrepreneurs in high states. Since the government cannot subsidize (or bailout) all the troubled projects at date 1, some of the troubled projects will suffer from the moral hazard problem if there is no private liquidation market. Whether there are entrepreneurs willing to take the short-term project and supply liquidity depends on the expected payoffs from the short-term project and the long-term project. We assume the government randomly chooses which projects to bailout when it does not have enough resources. The following proposition characterizes the situations in which the liquidation market coexists with a government bailout at date 1 .

Proposition 5: Suppose $\chi(\pi H+(1-\pi) L)<1$. Define $\omega \equiv \frac{\pi((\pi+(1-\pi) \delta) \varkappa H-1)}{(1-\pi)(\delta-(\pi+(1-\pi) \delta) \mathcal{L})}$. Then: 
If $\pi H+(1-\pi)[\omega L+(1-\omega) \delta T L] \geq 1+\frac{R}{2}+(L-\delta T L)\left(1-\frac{\delta T L-\gamma L}{R}\right)$, then all the entrepreneurs choose the long-term project at date 0. In this case, there will be no liquidity supplied at date 1. The government subsidizes a fraction $\omega$ of the troubled long-term projects and the remaining fraction 1- $\omega$ of the troubled longterm projects will suffer from the moral hazard problem.

(ii)

If $\pi H+(1-\pi)[\omega L+(1-\omega) \delta T L]<1+\frac{R}{2}+(L-\delta T L)\left(1-\frac{\delta T L-\gamma L}{R}\right)$, then there is a

fraction $\alpha^{*}$ of entrepreneurs choosing the long-term project at date 0, and a fraction (1- $\left.\alpha^{*}\right)$ entrepreneurs that choose the short-term project at date 0.

$$
\begin{gathered}
\alpha^{*}=\frac{R+\gamma L-Q^{*}}{(1+(1-\pi)(1-\omega)) R+\gamma-Q^{*}}, \text { where } \\
Q^{*}=\frac{(1+(1-\omega)(1-\pi)) R+(1+\gamma) L-\sqrt{(1+(1-\omega)(1-\pi)) R+(1+\gamma) L)^{2}-4\left(R\left(1+\frac{R}{2}-\pi H+L(1-\omega(1-\pi))\right)+\gamma^{2}\right)}}{2} \\
\in[\delta T L, L] \text { is the liquidation price at date } 1 .
\end{gathered}
$$

Proof: See Appendix.

Depending on the parameters, there may or may not be private liquidity provision. In either instance, not all entrepreneurs with troubled projects can be bailed out. The government cannot afford that, as there are not enough resources that can be taxed to subsidize the troubled entrepreneurs. The government randomly bails out the maximum number of troubled bank projects that it can afford, and in the remainder either risk is added or they go to the liquidation market. This may be viewed as a type of "forbearance," that is, the government policy results in some borrowers engaging in moral hazard. But, this is the socially optimal Second Best policy.

\section{B. Taxes and Government Bonds}

The government can improve matters because it has the power to overcome the market incompleteness. Entrepreneurs who invested in long-term projects at date 0, and then saw their prospects brighten, because they realized $\mathrm{H}$ on their project, have valuable resources, the capital gains on their project. But, they have no way to monetize these gains to create "liquidity" and provide equity to the troubled projects. The government, however, can monetize these gains by issuing government bonds, as follows. The government buys troubled projects from banks, paying with the newly created bonds. The government then forgives some of the debt of the entrepreneurs, to prevent them from engaging in moral hazard. The newly created bonds, held by 
the banks, are paid off at date 2 with the tax revenues raised from the lucky entrepreneurs who realized $\mathrm{H}$.

Alternatively, the government can tax banks that make loans to long-term projects at date 0 . The government then hoards the tax revenue and uses it to finance the bailouts at date 1 . Since the burden has to be borne by the entrepreneurs, banks will raise the face value of the debt to cover the tax they pay at date 0 . This would generate the same outcome as the government issuing bonds and tax at date 2 .

The fact that the government maximizes social welfare is also important for the argument. Suppose there is a private insurer who signs a contract with the bank and the entrepreneur at date 0 . The contract specifies that the bank has the right to sell the loan to the insurer at (pre-specified) price $\mathrm{P}=\delta(\mathrm{F}-\mathrm{t})$ at date 1 (a put option). However, contingent on the sale of the loan, the insurer must lower the face value of the debt to $\gamma \mathrm{L}$. If the bank does not sell the loan to the insurer at date 1 , it has to pay the insurer $t$ at date 2 . The problem with this contract is that it is subject to collusion between the profit-maximizing insurer and the bank. At date 1 the insurer can bribe the bank not to force the insurer to buy the loan, according to the contract. The insurer gives the bank $\mathrm{t}+\varepsilon$ ( $\varepsilon$ is a very small number) at date 1 if the bank agrees not to sell the loan; the bank accepts. Thus the insurer avoids losing P- $\gamma \mathrm{L}$. Therefore no bank sells loans and if entrepreneurs anticipate the collusion, they will not purchase insurance at date 0 . The government scheme works because the government is concerned with social welfare and does not want the entrepreneurs to add risk. The private insurer maximizes profits not social welfare.

\section{Discussion}

There is a long history to government bailouts of banking systems, either directly or via an asset management company, which is set up for the purpose of relieving banks of bad loans by buying them at a price that implicitly subsidizes the banks. The Reconstruction Finance Corporation loans to railroads during the Great Depression, the examples of Chrysler, Penn Central Railroad, and the current (post September 11) bailouts of the airlines in the U.S. are examples of government liquidity provision, as described above. By providing subsidized loans or loan guarantees, the government provided equity injections to these firms. ${ }^{16}$

From the viewpoint of the analysis above, bailouts occur when there is not enough private liquidity available to implement transfers of ownership quickly. Private agents anticipate that the government will supply liquidity, as indeed it does. Claessens, Djankov, and Klingebiel (1999) describe corporate sector bailouts in Indonesia, Korea, Malaysia, and Thailand. In the

\footnotetext{
${ }^{16}$ References for these cases were given in footnote 6 .
} 
aftermath of the Asian Crisis, Indonesia, Korea, Malaysia, and Thailand established centralized asset management companies. As a percent of GDP, the amounts of bank assets purchased by these asset management companies were: Indonesia, 20 percent; Korea, ten percent; Malaysia, 17 percent; and Thailand, 17.5 percent. Only the Philippines did not establish an asset management company. See Lindgren, et. al. (1999) for details of the bailouts resulting from the Asian Crisis. And, as mentioned in the Introduction, there are many more examples of large-scale corporate distress, including the transition economies, Latin American economies such as Mexico, as well as Scandinavian countries. In most of these cases, there was an associated systemic banking crisis. This situation is analyzed next.

\section{Bank Capital, Banking Crises, and Bailouts}

We now turn to the analysis of bailouts of banking systems. In the above equilibrium, we assumed that banks were always solvent. However, there is the possibility that a troubled project could turn a solvent bank into an insolvent bank. In this section, we provide more detail about the situation of the bank. We introduce a measure of the amount of equity in a bank. As a function of how well capitalized a bank is, it may or may not behave as in the above equilibrium. In particular, a weakly capitalized bank, faced with troubled projects, may itself face the moral hazard problem of seeking to add inefficient risk. That is, there will be no incentive to liquidate projects. This means that when projects are troubled, weak banks cause a knock-on effect, where banks and entrepreneurs find it in their joint interests to engage in moral hazard.

\section{A. Bank Capital Ratios and Bank Moral Hazard Problems}

Suppose a representative bank lends to a single entrepreneur at date 0 , and owes depositors an amount $\mathrm{D}$ at date 2. Imagine that the bank has some assets other than the projects discussed so far. These other assets have a payoff of $\mathrm{V}$, where $\mathrm{V}$ is a random variable that will be realized at date 2 . The date 2 realization will be $\mathrm{V}_{\mathrm{H}}$ with probability $\theta$ and $\mathrm{V}_{\mathrm{L}}$ with probability 1 $\theta$. However, non-verifiable information about the realization of $\mathrm{V}$ becomes known to the banks at date 1 .

We assume the risk associated with $\mathrm{V}$ is systematic and independent of the states of the long-term projects. In addition, we assume:

A10: $V_{H}>D$, and $V_{L}+1>D$, but $V_{L}+L<D$. That is, when the bank receives a negative shock and the project it lent to is also in trouble, the bank is insolvent even if it receives the entire cash flow from the troubled project, $L$. 
Now, even though it is efficient to forgive part of the debt or to liquidate troubled projects, it can happen that the bank has a moral hazard problem itself and prefers not to liquidate troubled projects.

Lemma 4: If, at date 1, a bank learns that the realization of $V$ is $V_{L}$, then the bank will not agree to renegotiate the debt contract or to liquidate a troubled project.

Proof: See Appendix.

Previously, successful renegotiation resulted because the bank was willing to forgive some debt or to share the proceeds of liquidation with the entrepreneur. Here, by refusing to share the benefits of liquidation with the entrepreneur (via debt forgiveness), the bank removes any incentive for the entrepreneur to liquidate the project. If the entrepreneur cannot benefit by selling the project, then there is no reason to sell; adding risk is the entrepreneur's optimal strategy when the state is L. The bank engages in moral hazard by refusing to renegotiate with the borrower, thereby enticing the entrepreneur to add risk. As a result, there is a chance, $\delta$, that the entrepreneur will be able to repay $\mathrm{F}$ at date 2 . In that case, the bank will be able to honor its date 2 obligations to repay $\mathrm{D}$ to depositors. ${ }^{17}$

Forgiveness or liquidation is now possible only if the bank's cash flow from its other business is $\mathrm{V}_{\mathrm{H}}$. The bank's moral hazard problem causes an additional inefficiency in the economy. If the realization of the systematic shock is $\mathrm{V}_{\mathrm{L}}$, then the liquidity demand at date 1 is zero. This happens with probability 1- $\theta$. Now, the equilibrium project choices at date 0 depend on $\theta$. We first examine the case when debt forgiveness would be feasible without the bank moral hazard problem.

Proposition 6: Suppose that $\chi \geq \frac{\delta}{\pi+\delta(1-\pi)}$, i.e., debt forgiveness is feasible at date 1. Then:

17 If depositors can observe which entrepreneurs are in the low state, they can run on the banks and withdraw their deposits forcing the banks to "liquidate" (that is, the bank assets would have to be sold to the liquidity suppliers). Once they run the banks, both the bank's equity and the entrepreneur's equity are zero. Projects will be sold in the liquidation market, and the proceeds will be used to honor deposit contracts. If depositors cannot observe which entrepreneurs are in the low state, they might mistakenly run the banks with healthy projects. If depositors anticipate they might run the good banks, it may be better for them not to run any banks. These issues are discussed at length in Gorton and Huang (2001) and, for the sake of brevity, are avoided here. Here, imagine that there is deposit insurance in place (though the reasons for this are not modeled.) 
(i)

If $\pi H+(1-\pi)[\theta L+(1-\theta) \delta T L] \geq 1+\frac{R}{2}$, then all entrepreneurs choose the long-term project at date 0. If $\pi H+(1-\pi)[\theta L+(1-\theta) \delta T L]<1+\frac{R}{2}$, then all entrepreneurs choose the short-term project at date 0 .

Proof: See Appendix.

Because of the bank's moral hazard problem, renegotiation fails when the bank's state is $V_{L}$. Ex ante, the value of the long-term project decreases. The above proposition shows that the problem can be so severe that the long-term project can even be dominated by the short-term project. Investment in the long-term projects is then abandoned.

Next, we study how the bank moral hazard problem affects the equilibrium in the case where debt forgiveness is not feasible.

Proposition 7: Suppose that $\chi<\frac{\delta}{\pi+\delta(1-\pi)}$, i.e., debt forgiveness is not feasible at date 1. Then: If $\pi H+(1-\pi) \delta T L>1+\frac{R}{2}+\theta(L-\delta T L)\left(1-\frac{\delta T L-\gamma L}{R}\right)$, then all entrepreneurs choose the long-term project at date 0. In this case, there will be no liquidity supply at date 1, and risk will be added for projects realizing the low state at date 1.

(ii) If $\pi H+(1-\pi)[\theta L+(1-\theta) \delta T L]<1+\frac{R}{2}$, then all entrepreneurs choose the shortterm project at date 0.

$$
\text { If } \pi \mathrm{H}+(1-\pi) \delta \mathrm{TL} \leq 1+\frac{\mathrm{R}}{2}+\theta(\mathrm{L}-\delta \mathrm{TL})\left(1-\frac{\delta \mathrm{TL}-\gamma \mathrm{L}}{\mathrm{R}}\right) \text { and }
$$

$\pi H+(1-\pi)[\theta L+(1-\theta) \delta T L] \geq 1+\frac{R}{2}$, then there exists a measure, $\alpha^{*}$, of entrepreneurs that choose the long-term project at date 0 , and a measure, (1- $\left.\alpha^{*}\right)$, of entrepreneurs that choose short-term project at date $0 . \alpha^{*}=\frac{\mathrm{R}+\gamma \mathrm{L}-\mathrm{Q}^{*}}{(2-\pi) \mathrm{R}+\gamma \mathrm{L}-\mathrm{Q}^{*}}$, where 
$Q^{*}=\frac{(2-\pi) R+(1+\gamma) L-\sqrt{((2-\pi) R+(1+\gamma) L)^{2}-4\left(\frac{R}{\theta}\left(1+\frac{R}{2}-\pi H-(1-\pi)(1-\theta) \delta T L+\theta L\right)+\gamma L^{2}\right)}}{2}$

$\in[\delta T L, L]$ is the liquidation price at date 1.

Proof: See Appendix.

The moral hazard problem with banks can result in troubled projects not being sold in the liquidation market at date 1 . This is a kind of market failure and adds inefficiency to the economy. Recall that $\theta$ is the chance of $\mathrm{V}_{\mathrm{H}}$ occurring. We can view $\theta$ as a measure of this additional inefficiency.

Corollary 2: Social welfare is increasing in $\theta$.

Proof: See Appendix.

The intuition is straightforward. Higher $\theta$ means banks have more capital and are less likely to want to engage in moral hazard. Consequently, by increasing $\theta$, the chance that a troubled project receives equity either from the lender by forgiveness or via the liquidation market is increased, and so efficiency in the economy is improved. If banks are weaker, however, then inefficiency increases.

\section{B. Government Bank Bailouts}

Government intervention can improve efficiency when there is the potential problem of banks engaging in moral hazard. When the state is low and banks have $\mathrm{V}_{\mathrm{L}}$, the government has to consider not only the entrepreneurs' moral hazard problem but also the banks' moral hazard problem. Therefore the government has to offer banks a larger amount to induce banks to sell their projects to the government. The next lemma shows how much the government needs to pay the banks to bailout the troubled projects.

Lemma 5: Suppose the face value of the debt is $F$, and the government's tax is $t$ at date 2. The government has to pay banks at least $P^{\prime} \equiv \delta(F-t)+(1-\delta)\left(D-V_{L}\right)$ to remove banks' moral hazard problem.

Proof: See Appendix. 
Although it seems that the banks' moral hazard problem will make government intervention less efficient, the First Best outcome can still be reached so long as the condition $\gamma(\pi \mathrm{H}+(1-\pi) \mathrm{L}) \geq 1$ is satisfied. The intuition is as follows. Anticipating that banks will get a higher price, P', at date 1, the net interest, (F-t), paid to banks can be lowered and thus the government can tax more (increase $t$ ) at date 2 to finance the subsidy at date 1 . In other words, the bank moral hazard problem requires more public liquidity at date 1 . However, due to the decrease in the interest paid to banks, the government has more liquidity available at date 1 . So long as we have $\gamma(\pi \mathrm{H}+(1-\pi) \mathrm{L}) \geq 1$, the government has enough public liquidity to bailout all troubled projects. The First Best outcome can be attained.

Proposition 8: If $\chi(\pi H+(1-\pi) L) \geq 1$, then government intervention can still generate the First Best outcome even if the potential banks' moral hazard problem exists. Entrepreneurs and banks sign debt contracts with a face value of $F=\frac{1-(1-\pi) \mu}{\pi}$. At date 1 , the government offers to buy the loan at price $P=\frac{\delta+\pi(1-\delta)\left(D-V_{L}\right)}{\pi+\delta(1-\pi)}$. Banks with troubled projects sell their loans to the government and banks with high state projects retain their loans and pay a tax of $t=\frac{1-(1-\pi) \gamma L}{\pi}-\frac{1-(1-\pi)(1-\delta)\left(D-V_{L}\right)}{\pi+\delta(1-\pi)}$ at date 2.

Proof: See Appendix.

If $\gamma(\pi \mathrm{H}+(1-\pi) \mathrm{L})<1$, government intervention cannot produce the First Best outcome because the government cannot levy enough taxes on entrepreneurs in high states. As in the case without the banks' moral hazard problem, it is possible that a liquidation market at date 1 is desirable. The following proposition characterizes the situations in which the liquidation market exists.

Proposition 9: Suppose $\chi(\pi H+(1-\pi) L)<1$. Define

$$
\begin{aligned}
& \omega \equiv \frac{\pi\left((\pi+(1-\pi) \delta) \gamma H+(1-\pi)(1-\delta)\left(D-V_{L}\right)-1\right)}{(1-\pi)\left(\delta+\pi(1-\delta)\left(D-V_{L}\right)-(\pi+(1-\pi) \delta) \gamma \mathrm{L}\right)} \text {. Then: } \\
& \text { (i) If } \pi \mathrm{H}+(1-\pi)[\omega \mathrm{L}+(1-\omega) \delta \mathrm{TL}]>1+\frac{\mathrm{R}}{2}+\theta(\mathrm{L}-\delta \mathrm{TL})\left(1-\frac{\delta \mathrm{TL}-\gamma \mathrm{L}}{\mathrm{R}}\right) \text {, then all the } \\
& \text { entrepreneurs choose the long-term project at date } 0 \text {. In this case, there will be } \\
& \text { no liquidity supplied at date 1. The government subsidizes a fraction } \omega \text { of the }
\end{aligned}
$$


troubled long-term projects and the remaining 1- $\omega$ fraction of the troubled longterm projects will suffer from the moral hazard problem.

(ii) If $\pi H+(1-\pi)[\omega L+(1-\omega) \delta T L]<1+\frac{R}{2}+\theta(L-\delta T L)\left(1-\frac{\delta T L-\chi L}{R}\right)$, then there is a fraction $\alpha^{*} \in(0,1)$ of entrepreneurs choosing the long-term project at date 0 , and a fraction (1- $\left.\alpha^{*}\right)$ of entrepreneurs that choose the short-term project at date 0.

$$
\begin{aligned}
& \alpha^{*}=\frac{R+\gamma-Q^{*}}{(1+(1-\pi)(1-\omega)) R+\gamma-Q^{*}}, \text { where } \\
& \mathrm{Q}^{*}=\frac{(1+(1-\omega)(1-\pi)) \mathrm{R}+(1+\gamma) \mathrm{L}-\sqrt{(1+(1-\omega)(1-\pi) \mathrm{R}+(1+\gamma) \mathrm{L})^{2}-4\left(\frac{\mathrm{R}}{\theta}\left(1+\frac{\mathrm{R}}{2}-\pi \mathrm{H}+\mathrm{L}(\theta-\omega(1-\pi))-(1-\pi)(1-\omega)(1-\theta) \delta \mathrm{TL}\right)+\gamma \mathrm{L}^{2}\right)}}{2}
\end{aligned}
$$

$\in[\delta T L, L]$ is the liquidation price at date 1 .

Proof: See Appendix.

If some projects are allowed to continue, because the government only bailouts out a fraction of them, then we may say that "forbearance" occurs.

\section{Discussion}

As mentioned in the Introduction, government bailouts of banking systems have recently become very common. Modern versions of the U.S. Reconstruction Finance Corporation have been used in many countries. In Mexico, for example, the Tequila crisis of 1994-95 resulted in massive losses for Mexican banks. A public restructuring vehicle, the Trust Fund for the Protection of Bank Savings (FOBAPROA), was initially used to (in part) buy loans from banks (see Honohan (no date) and de Luna Martinez (2000)). Argentinean banks also suffered during the Tequila crisis and the subsequent bank restructuring also involved public assistance from newly established public entities (see de la Torre (2000)). In Thailand, the Financial Institutions Development Fund, a distinct public entity was established following the crisis of 1997 . In Bulgaria, the government issued "Zunk" bond, government bonds that it used to substitute for unrecoverable bank loans. Cameroon also established a public vehicle, the Société de Recouvrement des Créances that replaced bad loans with government obligations on bank balance sheets. In Japan, there is the Financial Reconstruction Commission (see Nakaso (1999)). And there are many other examples (see Sheng (1996), Alexander, et. al., (1997), Enoch, Garcia, and Sundararajan (1999), Lindgren, et. al., (1999), and Klingebiel (2000)).

Bailouts are not without controversy. One issue concerns whether such government safety nets generate incentive problems that we have not included in the model. For example, in our model, entrepreneurs do not have an effort choice that determines the probability of the high 
and low state. If they had such a choice, anticipating that the government will bail them out in the low state, entrepreneurs would shirk and free ride on other entrepreneurs' efforts (those who work hard and pay tax to finance the bailouts). Then the ex post efficient government bailouts may cause an ex ante efficiency loss. And consequently, governments would like to commit to only bailout entrepreneurs under certain circumstances. This is an interesting and important topic, which we are pursuing. ${ }^{18}$

\section{Conclusion}

Bailouts by the government occur when the amount of the assets to be sold is so large that it would be inefficient for private agents to have hoarded liquid resources to purchase these assets in a short period of time. When the banking system is insolvent, private agents cannot readily buy the assets of the banks; it is simply not feasible since private agents lack liquidity. The government can improve welfare by creating this liquidity. However, forbearance occurs when the government cannot bailout all banks, corresponding to a situation where the government's tax capacity in the short-run is too small. ${ }^{19}$ These arguments stem from the basic idea that not all assets can be used to purchase other assets at every date.

"Liquidity" refers to the amount of readily available resources that can be used to purchase claims on projects when they are offered for sale at later dates. Not all resources can be used to buy projects. When there is a "liquidity-in-advance" constraint, the price at which claims can be sold is not just determined by the available information on their payoffs. Liquidity considerations result in prices that deviate from "efficient" market prices (i.e., the conditional expectation of the payoffs on the claim). A "liquidity discount" can arise.

At the root of the problem is the inability of private agents to buy insurance against declines in the value of their equity. Equity insurance is not available at date 0. Such insurance would have entrepreneurs with high value projects insure entrepreneurs with low value projects. But, this cannot occur. The incompleteness in markets raises the possibility that investment in the short-term project, what we have called hoarding, can be a desirable investment. Such investors commit to stand ready at subsequent dates to buy claims should they be offered for sale. These liquidity suppliers provide a valuable service when lender forgiveness is not optimal. But, from

\footnotetext{
${ }^{18}$ The obvious moral hazard problem seems to be hard to detect in empirical work, suggesting that the situation is more complicated. See Gorton and Winton (2002) for a survey of the literature.

${ }^{19}$ In our model, the constraint on the government is the amount that can be taxed at date 2. If this is too low, then not all banks can be bailed out. In reality, there may also be political constraints that prevent the government from raising taxes. For example, see Romer and Weingast (1992) with regard to the U.S. thrift crisis.
} 
society's point of view it is costly to have agents engage in this activity. The government can overcome the lack of an equity insurance market by subsidizing either distressed firms or banks. 


\section{Appendix}

Proof of Lemma 1: If the bank forgives the debt at date 1, the maximum the bank can get in the low state is $\mathrm{f}=\gamma L$. The face value of the debt, $\mathrm{F}$, that was set at date 0 , must be high enough such that $\pi \mathrm{F}+(1-\pi) \gamma \mathrm{L} \geq 1$, or $F \geq \frac{1-(1-\pi) \gamma}{\pi}$. But, in order for the bank to be willing to forgive debt, it must be the case that $\gamma \mathrm{L} \geq \delta \mathrm{F}$. Combining these two conditions, we get that $\chi \geq \frac{\delta}{\pi+\delta(1-\pi)} . / /$

Proof of Lemma 2: Suppose the liquidation price is Q and an entrepreneur who took the shortterm project has realized a cash flow of $r$. If $r \geq Q$, then he can afford to buy a troubled project by using his own money and no risk will be added. If $r<Q$, then he will have to borrow Q-r to buy the project. He adds risk if and only if Q-r $>\gamma \mathrm{L}$. The payoff to buying a project is L-Q if risk is not added; and is $\delta$ TL-Q if risk is added.

If $\mathrm{Q}>\mathrm{L}$, the liquidation price is greater than the continuation value of the troubled project even if risk is not added. Therefore, no one will buy. If $\mathrm{Q} \leq \delta \mathrm{TL}$, buying a troubled project is profitable even if risk is added and all liquidity suppliers want to buy. If $\delta \mathrm{TL}<\mathrm{Q} \leq \mathrm{L}$, then buying a troubled project is profitable only if risk is not added. Therefore, only those liquidity suppliers with $\mathrm{r} \leq \mathrm{Q}-\gamma \mathrm{L}$ will buy troubled projects. //

Proof of Lemma 3: At date 1, the total measure of troubled projects is $\alpha(1-\pi)$. The total measure of liquidity at a price $\mathrm{Q} \in[\delta \mathrm{TL}, \mathrm{L}]$ is $(1-\alpha)\left(1-\frac{\mathrm{Q}-\gamma \mathrm{L}}{\mathrm{R}}\right)$.

If $(1-\alpha)\left(1-\frac{\delta \mathrm{TL}-\gamma \mathrm{L}}{\mathrm{R}}\right) \leq \alpha(1-\pi)$, then liquidity demand is so high that there is no liquidation price, $\mathrm{Q}$, with $\mathrm{Q}>\delta \mathrm{TL}$, that clears the liquidation market. Bertrand competition then drives the price to the reservation value of $\delta \mathrm{TL}$.

If $\alpha(1-\pi) \leq(1-\alpha)\left(1-\frac{L-\gamma L}{R}\right)$, then there is an excess supply of liquidity at date 1 . The price is at its highest level, L.

Finally, if $(1-\alpha)\left(1-\frac{\mathrm{L}-\gamma \mathrm{L}}{\mathrm{R}}\right)<\alpha(1-\pi)<(1-\alpha)\left(1-\frac{\delta \mathrm{LT}-\gamma \mathrm{L}}{\mathrm{R}}\right)$, then there exists a $\mathrm{Q} \in$ $(\delta \mathrm{TL}, \mathrm{L})$ that clears the market. Equating liquidity demand to liquidity supply: 
$(1-\alpha)\left(1-\frac{\mathrm{Q}-\gamma \mathrm{L}}{\mathrm{R}}\right)=\alpha(1-\pi)$, results in $\mathrm{Q}=\gamma \mathrm{L}+\mathrm{R}\left(1-\frac{\alpha(1-\pi)}{1-\alpha}\right)$. All those entrepreneurs with $\mathrm{r} \geq$ $\delta \mathrm{TL}-\gamma \mathrm{L}$ get projects and will not add risk. //

Proof of Proposition 2: Suppose the liquidation price is Q. We know that Q must be in the interval $[\delta \mathrm{TL}, \mathrm{L}]$. At date 0 , the expected payoff to the long-term project is $\pi \mathrm{H}+(1-\pi) \mathrm{Q}$, which is increasing in $\mathrm{Q}$; the expected payoff to the short-term project is $1+\frac{\mathrm{R}}{2}+(\mathrm{L}-\mathrm{Q})\left(1-\frac{\mathrm{Q}-\gamma \mathrm{L}}{\mathrm{R}}\right)$, which is decreasing in $\mathrm{Q}$. When liquidation price $\mathrm{Q}$ is $\delta \mathrm{TL}$, the value of the long-term project reaches its minimum $\pi \mathrm{H}+(1-\pi) \delta \mathrm{TL}$, and the value of the short-term project reaches its maximum $1+\frac{\mathrm{R}}{2}+(\mathrm{L}-\delta \mathrm{TL})\left(1-\frac{\delta \mathrm{TL}-\gamma \mathrm{L}}{\mathrm{R}}\right)$. If $\pi \mathrm{H}+(1-\pi) \delta \mathrm{TL}>1+\frac{\mathrm{R}}{2}+(\mathrm{L}-\delta \mathrm{TL})\left(1-\frac{\delta \mathrm{TL}-\gamma \mathrm{L}}{\mathrm{R}}\right)$, then taking the long-term project dominates taking the short-term project. In that case, all entrepreneurs choose the long-term project at date $0 . \quad$ Suppose $\pi \mathrm{H}+(1-\pi) \delta \mathrm{TL} \leq 1+\frac{\mathrm{R}}{2}+(\mathrm{L}-\delta \mathrm{TL})\left(1-\frac{\delta \mathrm{TL}-\gamma \mathrm{L}}{\mathrm{R}}\right) . \quad$ Recall that we have assumed that $\pi \mathrm{H}+(1-$ $\pi) \mathrm{L}>1+\mathrm{R} / 2$. Therefore, there exists a unique $\mathrm{Q}^{*} \in[\delta \mathrm{TL}, \mathrm{L}]$ such that $\pi \mathrm{H}+(1-\pi) \mathrm{Q}^{*}=1+\frac{\mathrm{R}}{2}+\left(\mathrm{L}-\mathrm{Q}^{*}\right)\left(1-\frac{\mathrm{Q}^{*}-\gamma \mathrm{L}}{\mathrm{R}}\right)$. Solving for $\mathrm{Q}^{*}$, we get:

$Q^{*}=\frac{(2-\pi) R+(1+\gamma) L-\sqrt{((2-\pi) R+(1+\gamma) L)^{2}-4\left(R\left(1+\frac{R}{2}-\pi H+L\right)+\chi^{2}\right)}}{2}$.

To obtain $\alpha^{*}$, the secondary liquidation market must be cleared at date 1 , i.e., $(1-\alpha)\left(1-\frac{\mathrm{Q}^{*}-\gamma \mathrm{L}}{\mathrm{R}}\right)=\alpha(1-\pi)$. Solving this equation gives: $\alpha^{*}=\frac{\mathrm{R}+\gamma \mathrm{L}-\mathrm{Q}^{*}}{(2-\pi) \mathrm{R}+\gamma \mathrm{L}-\mathrm{Q}^{*}}$. //

Proof of Proposition 3 and Corollary 1: (1) Define:

$$
\begin{aligned}
& \mathrm{G}\left(\pi, \delta, \mathrm{R}, \mathrm{Q}^{*}\right)=\pi \mathrm{H}+(1-\pi) \mathrm{Q}^{*}-1-\frac{\mathrm{R}}{2}-\left(\mathrm{L}-\mathrm{Q}^{*}\right)\left(1-\frac{\mathrm{Q}^{*}-\gamma \mathrm{L}}{\mathrm{R}}\right) . \\
& \frac{\partial \mathrm{Q}^{*}}{\partial \mathrm{R}}=-\frac{\partial \mathrm{G} / \partial \mathrm{R}}{\partial \mathrm{G} / \partial \mathrm{Q}^{*}}=\frac{\frac{1}{2}+\frac{\left(\mathrm{L}-\mathrm{Q}^{*}\right)\left(\mathrm{Q}^{*}-\gamma \mathrm{L}\right)}{\mathrm{R}^{2}}}{(1-\pi)+\left(1-\frac{\mathrm{Q}^{*}-\gamma \mathrm{L}}{\mathrm{R}}\right)+\frac{\mathrm{L}-\mathrm{Q}^{*}}{\mathrm{R}}}>0 \\
& \frac{\partial \mathrm{Q}^{*}}{\partial \pi}=-\frac{\partial \mathrm{G} / \partial \pi}{\partial \mathrm{G} / \partial \mathrm{Q}^{*}}=-\frac{\mathrm{H}-\mathrm{Q}^{*}}{(1-\pi)+\left(1-\frac{\mathrm{Q}^{*}-\gamma \mathrm{L}}{\mathrm{R}}\right)+\frac{\mathrm{L}-\mathrm{Q}^{*}}{\mathrm{R}}}<0
\end{aligned}
$$




$$
\frac{\partial \mathrm{Q}^{*}}{\partial \delta}=-\frac{\partial \mathrm{G} / \partial \delta}{\partial \mathrm{G} / \partial \mathrm{Q}^{*}}=-\frac{\frac{\left(\mathrm{L}-\mathrm{Q}^{*}\right) \mathrm{L}(\mathrm{T}-1)}{\mathrm{R}(1-\delta)^{2}}}{(1-\pi)+\left(1-\frac{\mathrm{Q}^{*}-\gamma \mathrm{L}}{\mathrm{R}}\right)+\frac{\mathrm{L}-\mathrm{Q}^{*}}{\mathrm{R}}}<0
$$

(2) To prove that social welfare is increasing in $\mathrm{R}$ and $\delta$, we use the expected payoff to entrepreneurs who take the long-term project. Define $\mathrm{V}=\pi H+(1-\pi) Q^{*}$. Then:

$\frac{\partial \mathrm{V}}{\partial \mathrm{R}}=(1-\pi) \frac{\partial \mathrm{Q}^{*}}{\partial \mathrm{R}}>0$, and $\frac{\partial \mathrm{V}}{\partial \delta}=(1-\pi) \frac{\partial \mathrm{Q}^{*}}{\partial \delta}>0$. To prove that social welfare is decreasing in $\pi$, we use the expected payoff to entrepreneurs who take the short-term project. Define $\mathrm{V}=$ $1+\frac{\mathrm{R}}{2}+\left(\mathrm{L}-\mathrm{Q}^{*}\right)\left(1-\frac{\mathrm{Q}^{*}-\gamma \mathrm{L}}{\mathrm{R}}\right)$. Then, $\frac{\partial \mathrm{V}}{\partial \pi}=-\left(\frac{\left(\mathrm{L}-\mathrm{Q}^{*}\right)}{\mathrm{R}}+1-\frac{\mathrm{Q}^{*}-\gamma \mathrm{L}}{\mathrm{R}}\right) \frac{\partial \mathrm{Q}^{*}}{\partial \pi}>0 . / /$

Proof of Proposition 4: Suppose the face value of the debt is F and the government levies $t$ on each bank at date 2. F-t is the net payment a bank receives from a loan in the high state. When the government buys the loans from banks at date 1, the minimum price it has to pay to the banks is $\delta(\mathrm{F}-\mathrm{t})$. And, in order to remove the incentive to engage in moral hazard, the government has to forgive the face value of the debt to less than or equal to $\gamma \mathrm{L}$. Therefore, $\delta(F-t)-\gamma L$ is the necessary subsidy to bailout a troubled project. The government has a budget constraint condition: $\pi \mathrm{t} \geq(1-$ $\pi)(\delta(F-t)-\gamma L)$. Banks have to break even, so we have $\pi(F-t)+(1-\pi) \delta(F-t) \geq 1$. Finally, the face value of the debt cannot be too high; otherwise even entrepreneurs in the high state will add risk. So, we must have $\mathrm{F} \leq \gamma \mathrm{H}$. Combining these conditions, we obtain $\gamma(\pi \mathrm{H}+(1-\pi) \mathrm{L}) \geq 1$. The equilibrium is the solution to the following system of equations: $\mathrm{P}=\delta(\mathrm{F}-\mathrm{t}), \pi \mathrm{t}=(1-\pi)(\mathrm{P}-\gamma \mathrm{L})$, $\pi(\mathrm{F}-\mathrm{t})+(1-\pi) \mathrm{P}=1$. Solving for the equilibrium gives us: $\mathrm{F}=\frac{1-(1-\pi) \chi}{\pi}, \mathrm{P}=\frac{\delta}{\pi+\delta(1-\pi)}$, and $t=\frac{1-(1-\pi) \gamma}{\pi}-\frac{1}{\pi+\delta(1-\pi)}$

Proof of Proposition 5: We first examine the best the government can do by taxing the entrepreneurs in the high state and subsidizing entrepreneurs in the low state. Suppose the face value of the debt is $\mathrm{F}$ and the government levies tax $\mathrm{t}$ on each bank at date 2. As in the proof of Proposition 4, we must have $\mathrm{F} \leq \gamma \mathrm{H}$ to prevent entrepreneurs in high states from engaging in moral hazard. Moreover, banks have to break even, i.e., $\pi(F-t)+(1-\pi) \delta(F-t)=1$. Therefore, the tax that the government can collect is $\mathrm{t}=\mathrm{F}-\frac{1}{\pi+(1-\pi) \delta}$. Since the government has to subsidize each troubled project by the amount $\delta(\mathrm{F}-\mathrm{t})-\gamma \mathrm{L}$, the fraction of troubled projects that can be subsidized 
is equal to $\frac{(\pi+(1-\pi) \mathrm{d}) \mathrm{F}-1}{(1-\pi)(\delta \mathrm{F}-\gamma \mathrm{L})}$. This fraction is maximized when $\mathrm{F}$ is equal to $\gamma \mathrm{H}$. The maximum is equal to $\omega \equiv \frac{\pi((\pi+(1-\pi) \delta) \gamma \mathrm{H}-1)}{(1-\pi)(\delta-(\pi+(1-\pi) \delta) \gamma \mathrm{L})}$. Note that $\omega$ is always less than one because we have $\gamma(\pi \mathrm{H}+(1-\pi) \mathrm{L})<1$. The remaining $(1-\omega)$ projects cannot be bailed out by the government. Risk will be added to these projects if they are not liquidated. Then the question is whether there are liquidity suppliers in the secondary market. We need to check whether a deviation to the shortterm project is profitable if all other entrepreneurs take the long-term project.

If all other entrepreneurs take the long-term project, and one entrepreneur takes the shortterm project, then this entrepreneur is the sole liquidity supplier at date 1 and he can buy a troubled project at the reservation price $\delta \mathrm{TL}$. His expected payoff from taking the short-term project is: $1+\frac{\mathrm{R}}{2}+(\mathrm{L}-\delta \mathrm{TL})\left(1-\frac{\delta \mathrm{TL}-\gamma \mathrm{L}}{\mathrm{R}}\right)$. If this entrepreneur does not deviate, his expected payoff is: $\pi \mathrm{H}+(1-\pi)[\omega \mathrm{L}+(1-\omega) \delta \mathrm{TL}]$ Therefore, there are liquidity suppliers if and only if $\pi \mathrm{H}+(1-\pi)[\omega \mathrm{L}+(1-\omega) \delta \mathrm{TL}] \leq 1+\frac{\mathrm{R}}{2}+(\mathrm{L}-\delta \mathrm{TL})$.

The remainder of the proof is similar to the proof of Proposition 2. Since entrepreneurs must be indifferent between taking the-term short-term project and taking the long-term project at date 1 , the liquidation price $\mathrm{Q}^{*}$ must satisfy

$$
\begin{aligned}
& \pi \mathrm{H}+(1-\pi)[\omega \mathrm{L}+(1-\omega) \mathrm{Q}]=1+\frac{\mathrm{R}}{2}+(\mathrm{L}-\mathrm{Q})\left(1-\frac{\mathrm{Q}-\gamma \mathrm{L}}{\mathrm{R}}\right) . \text { Solving for } \mathrm{Q}^{*}, \text { we get: } \\
& \mathrm{Q}^{*}=\frac{(1+(1-\omega)(1-\pi)) R+(1+\gamma) L-\sqrt{(1+(1-\omega)(1-\pi)) R+(1+\gamma) L)^{2}-4\left(R\left(1+\frac{R}{2}-\pi H+L(1-\omega(1-\pi))\right)+\mathcal{L}^{2}\right)}}{2} .
\end{aligned}
$$

Finally, substituting $\mathrm{Q}^{*}$ into the market clearing condition at date 1 gives: $\alpha(1-\pi)(1-\omega)=(1-\alpha)\left(1-\frac{Q^{*}-\gamma \mathrm{L}}{\mathrm{R}}\right) . \quad$ Solving this equation gives us $\alpha^{*}=\frac{R+\gamma-Q^{*}}{(1+(1-\pi)(1-\omega)) R+\gamma-Q^{*}} . / /$

Proof of Lemma 4: The bank can get at most L from forgiveness or liquidation. In these cases, its equity is negative. Therefore, the bank will not forgive debt or sell the project, forcing continuation with risk added. In that case, there is till some hope that the bank will be solvent at date 2. //

Proof of Proposition 6: If the systematic shock turns out to be high, i.e. V is equal to $V_{H}$, then there will be debt forgiveness and the value of the project is $\mathrm{L}$ in the low state. If the systematic 
shock turns out to be low, i.e. $\mathrm{V}$ is equal to $\mathrm{V}_{\mathrm{L}}$, then there will be no debt forgiveness by Lemma 5 and the value of the project is $\delta \mathrm{TL}$ in the low state. Therefore the expected payoff from taking the long-term project is $\pi \mathrm{H}+(1-\pi)[(1-\theta) \delta \mathrm{TL}+\theta \mathrm{L}]$. On the other hand, if an entrepreneur takes a short-term project, there is no chance for him to buy a troubled project and hence the expected payoff is $1+\frac{R}{2}$. At date 0 entrepreneurs make investment decisions by comparing these two expected values. //

Proof of Proposition 7: If $\pi \mathrm{H}+(1-\pi) \delta \mathrm{TL}>1+\frac{\mathrm{R}}{2}+\theta(\mathrm{L}-\delta \mathrm{TL})\left(1-\frac{\delta \mathrm{TL}-\gamma \mathrm{L}}{\mathrm{R}}\right)$, then the return to the long-term project dominates that of the short-term project even if the date 1 liquidation price is at its reservation value $\delta \mathrm{TL}$. Therefore, no entrepreneur invests in the short-term project at date 0 .

If $\pi \mathrm{H}+(1-\pi)[(1-\theta) \delta \mathrm{TL}+\theta \mathrm{L}] \leq 1+\frac{R}{2}$. Then even if the troubled project can be sold for its maximum value of $\mathrm{L}$ in the liquidation market, $\theta$ is so low that, ex ante, the payoff from a longterm project is less than the payoff from a short-term project. No entrepreneur chooses the longterm project at date 0 .

Suppose $\pi \mathrm{H}+(1-\pi) \delta \mathrm{TL} \leq 1+\frac{\mathrm{R}}{2}+\theta(\mathrm{L}-\delta \mathrm{TL})\left(1-\frac{\delta \mathrm{TL}-\gamma \mathrm{L}}{\mathrm{R}}\right)$ and $\pi \mathrm{H}+(1-\pi)[(1-\theta) \delta \mathrm{TL}+\theta \mathrm{L}]$ $>1+\frac{R}{2}$. Then there is a unique liquidation price, $\mathrm{Q}^{*}$, that solves the equation: $\pi \mathrm{H}+(1-\pi)[(1-\theta) \delta \mathrm{TL}+\theta \mathrm{Q}]=1+\frac{\mathrm{R}}{2}+\theta(\mathrm{L}-\mathrm{Q})\left(1-\frac{\mathrm{Q}-\gamma \mathrm{L}}{\mathrm{R}}\right)$. Solving this equation, we get $\mathrm{Q}^{*}=\frac{(2-\pi) \mathrm{R}+(1+\gamma) \mathrm{L}-\sqrt{((2-\pi) \mathrm{R}+(1+\gamma) \mathrm{L})^{2}-4\left(\frac{\mathrm{R}}{\theta}\left(1+\frac{\mathrm{R}}{2}-\pi \mathrm{H}-(1-\pi)(1-\theta) \delta \mathrm{TL}+\theta \mathrm{L}\right)+\gamma \mathrm{L}^{2}\right)}}{2}$.

Q* an individual entrepreneur is indifferent between choosing the long-term project or the shortterm project at date 0 . Equilibrium project choice must be consistent with $\mathrm{Q}^{*}$, so $\alpha^{*}$ is the solution to the equation: $(1-\alpha)\left(1-\frac{\mathrm{Q}^{*}-\gamma \mathrm{L}}{\mathrm{R}}\right)=\alpha(1-\pi)$. Solving for $\alpha^{*}$, we get $\alpha^{*}=\frac{\mathrm{R}+\gamma \mathrm{L}-\mathrm{Q}^{*}}{(2-\pi) \mathrm{R}+\gamma \mathrm{L}-\mathrm{Q}^{*}} . / /$

Proof of Corollary 2: When debt forgiveness is feasible, social welfare is equal to $\max \left\{\pi \mathrm{H}+(1-\pi)[\theta \mathrm{L}+(1-\theta) \delta \mathrm{TL}], 1+\frac{\mathrm{R}}{2}\right\}$, which is increasing in $\theta$. Suppose debt forgiveness is not 
feasible. If all entrepreneurs take the short-term project or all entrepreneurs take the long-term project, there is no liquidation market. Social welfare is either $\pi H+(1-\pi) \delta T L$ or $1+\frac{R}{2}$. If entrepreneurs choose different projects and there is a liquidation market at date 1 , social welfare is equal to

$\pi \mathrm{H}+(1-\pi)[\theta \mathrm{Q}+(1-\theta) \delta \mathrm{TL}] . \quad$ Let $\mathrm{W}(\theta) \equiv \pi \mathrm{H}+(1-\pi)[\theta \mathrm{Q}+(1-\theta) \delta \mathrm{TL}] . \quad$ We have $\mathrm{W}^{\prime}(\theta)=(1-\pi)\left[\mathrm{Q}-\delta \mathrm{TL}+\theta \frac{\partial \mathrm{Q}}{\partial \theta}\right]>0 . / /$

Proof of Lemma 5: To make $\mathrm{V}_{\mathrm{L}}$ banks sell the troubled projects, the government has to pay a price, $\mathrm{P}^{\prime}$, such that $\mathrm{V}_{\mathrm{L}}+\mathrm{P}^{\prime}-\mathrm{D} \geq \delta\left(\mathrm{V}_{\mathrm{L}}+\mathrm{F}-\mathrm{t}-\mathrm{D}\right)$. Rearranging the terms, we get $\mathrm{P}^{\prime} \geq \delta(\mathrm{F}-\mathrm{t})+(1-\delta)(\mathrm{D}-$ $\left.\mathrm{V}_{\mathrm{L}}\right)$. //

Proof of Proposition 8: Suppose the face value of the debt is F and the government levies tax $t$ on each bank at date 2. By Lemma 6, when the government buys the claims from banks at date 1, the minimum price it has to pay to the banks is $\delta(F-t)+(1-\delta)\left(D-V_{L}\right)$. And in order to remove the entrepreneurs' incentives to engage in moral hazard, the government has to forgive the face value of the debt to less than or equal to $\gamma \mathrm{L}$. The government has a budget constraint: $\pi \mathrm{t} \geq(1-\pi)(\delta(\mathrm{F}-$ t) $\left.+(1-\delta)\left(D-V_{L}\right)-\gamma L\right)$. Banks have to break even, so we have $\pi(F-t)+(1-\pi)\left(\delta(F-t)+(1-\delta)\left(D-V_{L}\right.\right.$ )) $\geq 1$. Finally, the face value of the debt cannot be too high because otherwise even entrepreneurs in the high state will add risk. So, we must have $\mathrm{F} \leq \gamma \mathrm{H}$. Combining these conditions, we obtain $\gamma(\pi \mathrm{H}+(1-\pi) \mathrm{L}) \geq 1$. The equilibrium is the solution to the following system of equations: $\mathrm{P}=\delta(\mathrm{F}-\mathrm{t})$ $+(1-\delta)\left(\mathrm{D}-\mathrm{V}_{\mathrm{L}}\right), \pi \mathrm{t}=(1-\pi)(\mathrm{P}-\gamma \mathrm{L}), \pi(\mathrm{F}-\mathrm{t})+(1-\pi) \mathrm{P}=1$. Solving for the equilibrium gives us: $\mathrm{F}=\frac{1-(1-\pi) \gamma L}{\pi}, \mathrm{P}=\frac{\delta+\pi(1-\delta)\left(D-V_{L}\right)}{\pi+\delta(1-\pi)}$, and $t=\frac{1-(1-\pi) \gamma L}{\pi}-\frac{1-(1-\pi)(1-\delta)\left(D-V_{L}\right)}{\pi+\delta(1-\pi)}$. //

Proof of Proposition 9: First we examine the best the government can do collect by taxing the entrepreneurs in the high state and subsidizing some of the entrepreneurs in the low state. Suppose the face value of the debt is $\mathrm{F}$ and the government levies $\mathrm{t}$ from each bank at date 2 . As in proof of Proposition 10, we must have $\mathrm{F} \leq \gamma \mathrm{H}$ in order to prevent entrepreneurs in high states from engaging in moral hazard. Moreover, banks have to break even: $\pi(F-t)+(1-\pi)(\delta(F-t)+(1-$ $\left.\delta)\left(D-V_{L}\right)\right) \geq 1$. Therefore, the tax the government can collect is $t=F-\frac{1-(1-\pi)(1-\delta)\left(D-V_{L}\right)}{\pi+(1-\pi) \delta}$. Since the government has to subsidize each troubled project by the amount $\delta(F-t)+(1-\delta)\left(D-V_{L}\right)-$ $\gamma \mathrm{L}$, the fraction of troubled projects that can be subsidized is equal to 
$\frac{\pi t}{(1-\pi)\left(\delta(F-t)+(1-\delta)\left(D-V_{L}\right)-\gamma L\right)}$. This fraction is maximized when $F$ is equal to $\gamma H$. The maximum is equal to $\omega \equiv \frac{\pi\left((\pi+(1-\pi) \delta) \gamma H+(1-\pi)(1-\delta)\left(D-V_{L}\right)-1\right)}{(1-\pi)\left(\delta+\pi(1-\delta)\left(D-V_{L}\right)-(\pi+(1-\pi) \delta) \gamma L\right)}$. Note that $\omega$ is always less than one because we have $\gamma(\pi \mathrm{H}+(1-\pi) \mathrm{L})<1$. The remaining $(1-\omega)$ projects cannot be bailed out by the government and risk will be added to these projects if they are not liquidated.

The next question is whether there are liquidity suppliers in the secondary market. We need to check whether deviation to the short-term project is profitable if all other entrepreneurs take the long-term project. If all other entrepreneurs take the long-term project, and one entrepreneur takes the short-term project, then this entrepreneur is the sole liquidity supplier at date 1 and he can buy a troubled project at price $\delta$ TL. His expected payoff from taking the shortterm project is:

$1+\frac{R}{2}+\theta(L-\delta T L)\left(1-\frac{\delta T L-\gamma L}{R}\right)$. If this entrepreneur does not deviate, his expected payoff is: $\pi \mathrm{H}+(1-\pi)[\omega \mathrm{L}+(1-\omega) \delta \mathrm{TL}]$. Therefore, there are liquidity suppliers if and only if $\pi \mathrm{H}+(1-\pi)[\omega \mathrm{L}+(1-\omega) \delta \mathrm{TL}] \leq 1+\frac{\mathrm{R}}{2}+\theta(\mathrm{L}-\delta \mathrm{TL})\left(1-\frac{\delta \mathrm{TL}-\gamma \mathrm{L}}{\mathrm{R}}\right)$.

The remainder of the proof is similar to the proof of Proposition 8. Since entrepreneurs must be indifferent between taking the short-term project and taking the long-term project at date 1 , the liquidation price $\mathrm{Q}^{*}$ must satisfy:

$$
\begin{array}{r}
\pi \mathrm{H}+(1-\pi)[\omega \mathrm{L}+(1-\omega)(\theta \mathrm{Q}+(1-\theta) \delta \mathrm{TL})]=1+\frac{\mathrm{R}}{2}+\theta(\mathrm{L}-\mathrm{Q})\left(1-\frac{\mathrm{Q}-\gamma \mathrm{L}}{\mathrm{R}}\right) \text {. Solving for } \mathrm{Q}^{*} \text {, we get: } \\
\mathrm{Q}^{*}=\frac{(1+(1-\omega)(1-\pi)) \mathrm{R}+(1+\gamma) \mathrm{L}-\sqrt{(1+(1-\omega)(1-\pi)) \mathrm{R}+(1+\gamma) \mathrm{L})^{2}-4\left(\frac{\mathrm{R}}{\theta}\left(1+\frac{\mathrm{R}}{2}-\pi \mathrm{H}+\mathrm{L}(\theta-\omega(1-\pi))-(1-\pi)(1-\omega)(1-\theta) \delta \mathrm{TL}\right)+\gamma \mathrm{L}^{2}\right)}}{2}
\end{array}
$$

Once we get $\mathrm{Q}^{*}$, we plug $\mathrm{Q}^{*}$ into the market clearing condition at date 1: $\alpha(1-\pi)(1-\omega)=(1-\alpha)\left(1-\frac{\mathrm{Q}-\gamma \mathrm{L}}{\mathrm{R}}\right)$. Solving this equation gives us: $\alpha^{*}=\frac{R+\gamma L-Q^{*}}{(1+(1-\pi)(1-\omega)) R+\gamma L-Q^{*}} . / /$ 


\section{References}

Alexander, William, Jeffrey Davis, Liam Ebrill, and Carl-John Lindgren (1997), Systemic Bank Restructuring and Macroeconomic Policy (Washington D.C.; International Monetary Fund).

Barth, James (1991), The Great Savings and Loan Debacle (AEI Press; Washington D.C.).

Barth, James and Philip Bartholomew (1992), "The Thrift Crisis: Revealed Weaknesses in the Federal Deposit Insurance System," in The Reform of Federal Deposit Insurance, edited by James Barth and Dan Brumbaugh (HarperBusiness).

Brumbaugh, R. Dan (1988), Thrifts Under Siege (Ballinger Publishing Company; Cambridge, Massachusetts).

Calomiris, Charles (1994), "Is the Discount Window Necessary? A Penn Central Perspective?," Federal Reserve Bank of St. Louis Review (May/June), 31-55.

Caprio, Gerard and Daniela Klingebiel (1999), "Episodes of Systemic and Borderline Financial Crises," World Bank, mimeo.

Caprio, Gerard and Daniela Klingebiel (1996), "Bank Insolvencies: Cross Country Experience," World Bank, Policy Research Working Paper No. 1620.

Claessens, Stijn, Simeon Djankov, and Daniela Klingebiel (1999), "Financial Restructuring in East Asia: Halfway There?," World Bank, Financial Sector Discussion Paper No. 3.

Daniel, James A. (1997), “Fiscal Aspects of Bank Restructuring,” IMF Working Paper.

De la Torre, Augusto (2000), "Resolving Bank Failures in Argentina: Recent Developments and Issues,” World Bank Policy Research Working Paper 2295.

De Luna Martinez, Jose (2000), "Management and Resolution of Banking Crises: Lessons from the Republic of Korea and Mexico," World Bank Discussion Paper 413.

Diamond, Douglas (2001), "Should Banks Be Recapitalized?," Federal Reserve Bank of Richmond Quarterly Review 87, 71-96.

Diamond, Douglas and Philip Dybvig (1983), "Bank Runs, Deposit Insurance, and Liquidity," Journal of Political Economy 91, 401-419.

Diamond, Douglas and Raghuram Rajan (2001), "Liquidity Risk, Liquidity Creation, and Financial Fragility: A Theory of Banking," Journal of Political Economy 109, 287-327.

Diamond, Douglas and Raghuram Rajan (2002), "Bank Bailouts and Aggregate Liquidity," unpublished paper, University of Chicago.

Eisfeldt, Andrea (2002), "Endogenous Liquidity in Asset Markets," Kellogg School, Northwestern University, unpublished paper.

Enoch, Charles, Gillian Garcia, and V. Sundararajan (1999), "Recapitalizing Banks with Public Funds: Selected Issues," IMF Working Paper 99/139. 
Goodhart, Charles A.E. (1995), The Central Bank and the Financial System (London, Macmillan).

Gorton, Gary and Lixin Huang (2001), "Bank Panics and the Endogeneity of Central Banking," Wharton School, working paper.

Gorton, Gary and George Pennacchi (1990), "Financial Intermediaries and Liquidity Creation," Journal of Finance 45, 49-72.

Gorton, Gary and Andrew Winton (2002), "Financial Intermediation," chapter in The Handbook of the Economics of Finance (North Holland) edited by George Constantinides, Milton Harris, and René Stulz (forthcoming 2002).

Grossman, Sanford (1988), "An Analysis of the Implications for Stock and Futures Price Volatility of Program Trading and Dynamic Hedging Strategies," Journal of Business 61, 275-298.

Holmström, Bengt and Jean Tirole (1998), "Private and Public Supply of Liquidity," Journal of Political Economy 106, 1-40.

Honohan, Patrick (no date), "Recapitalizing Banking Systems: Implications for Incentives and Fiscal and Monetary Policy," World Bank, working paper 2540.

Honohan, Patrick and Daniela Klingebiel (2000), "Controlling Fiscal Costs of Bank Crises," World Bank, working paper 2441.

Hopenhayn, Hugo and Ingrid Werner (1996), "Information, Liquidity, and Asset Trading in a Random Matching Game," Journal of Economic Theory 68, 349-379.

Iacoca, Lee and William Novak (1986), Iacoca: An Autobiography (Bantam Books; New York).

Kane, Edward (1987), "Dangers of Capital Forbearance: The Case of the FSLIC and 'Zombie' S\&Ls," Contemporary Policy Issues (5), 77-83.

Kane, Edward (1989), The S\&L Mess: How Did It Happen? (The Urban Institute Press; Washington D.C.).

Kane, Edward and Min-The Yu (1996), "Opportunity Cost of Capital Forbearance during the Final Years of the FSLIC Mess," Quarterly Review of Economics and Finance 36, 271290.

Klingebiel, Daniela (2000), "The Use of Asset Management Companies in the Resolution of Banking Crises: Cross-Country Experience," World Bank Policy Research Working Paper 2284.

Kyle, Albert S. (1985), "Continuous Auctions and Insider Trading," Econometrica 53, 13351355.

Lindgren, Carl-Johan, Tomás J.T. Baliño, Charles Enoch, Anne-Marie Gulde, Marc Quintyn, and Leslie Teo (1999), "Financial Sector Crisis and Restructuring: Lessons From Asia," International Monetary Fund Occasional Paper No. 188. 
Lowenstein, Roger (2000), When Genius Failed (Random House; New York).

Lummer, Scott and John McConnell (1989), "Further Evidence on the Bank Lending Process and the Capital Market Responses to Bank Loan Agreements," Journal of Financial Economics 25, 99-122.

Nakaso, Hiroshi (1999), "Recent Banking Sector Reforms in Japan," Federal Reserve Bank of New York Economic Policy Review (July), 1-7.

Olson, James Stuart (1977), Herbert Hoover and the Reconstruction Finance Corporation, 19311933 (The Iowa State University Press; Ames, Iowa).

Romer, Thomas, and Barry Weingast (1992), "Political Foundations of the Thrift Debacle," in The Reform of Federal Deposit Insurance, edited by James Barth and Dan Brumbaugh (HarperBusiness).

Sheng, Andrew, editor (1996), Bank Restructuring: Lessons from the 1980s (Washington D.C.; The World Bank).

Shleifer, Andrei and Robert Vishny (1992), "Liquidation Values and Debt Capacity: A Market Equilibrium Approach,” Journal of Finance 47, 1343-1366.

Todd, Walker (1992), "History of and Rationales for the Reconstruction Finance Corporation," Federal Reserve Bank of Cleveland Economic Review, Quarter 4, 22-35.

Townsend, Robert (1979), "Optimal Contracts and Competitive Markets with Costly State Verification," Journal of Economic Theory, 21, 265-293.

White, Lawrence (1991), The S\&L Debacle: Public Policy Lessons for Bank and Thrift Regulation (Oxford University Press; New York). 


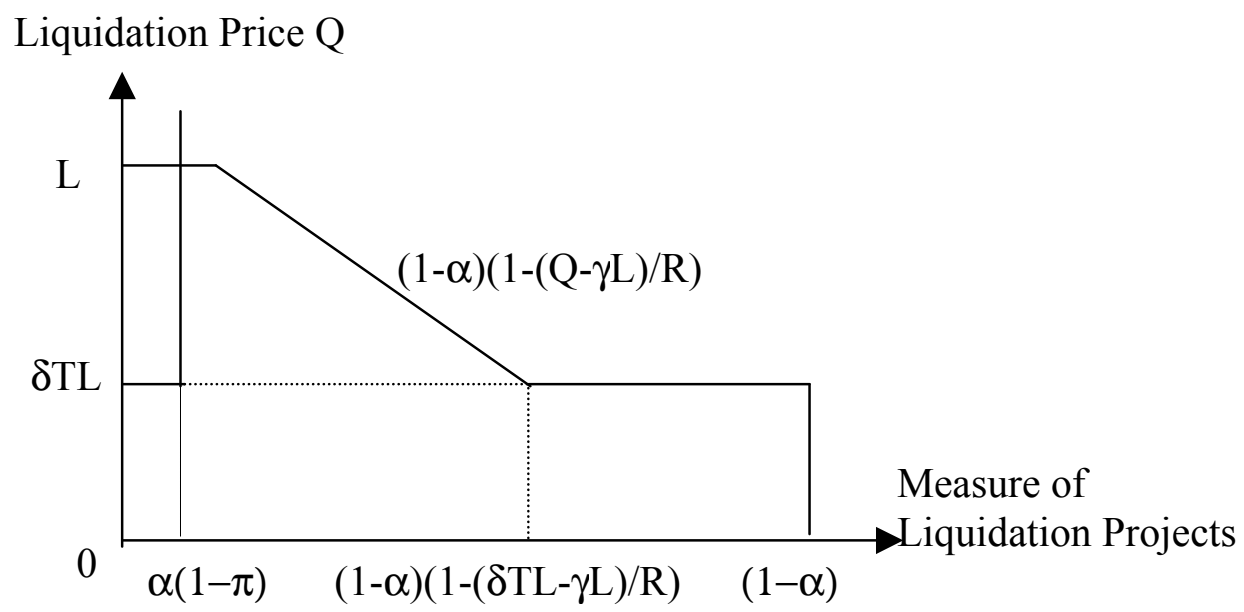

Figure $1, \mathrm{Q}^{*}=\mathrm{L}$

When $\alpha$ is small, there is excess liquidity supply in the liquidation market. The liquidation price is equal to the continuation value of the project and the liquidity premium is equal to zero. 


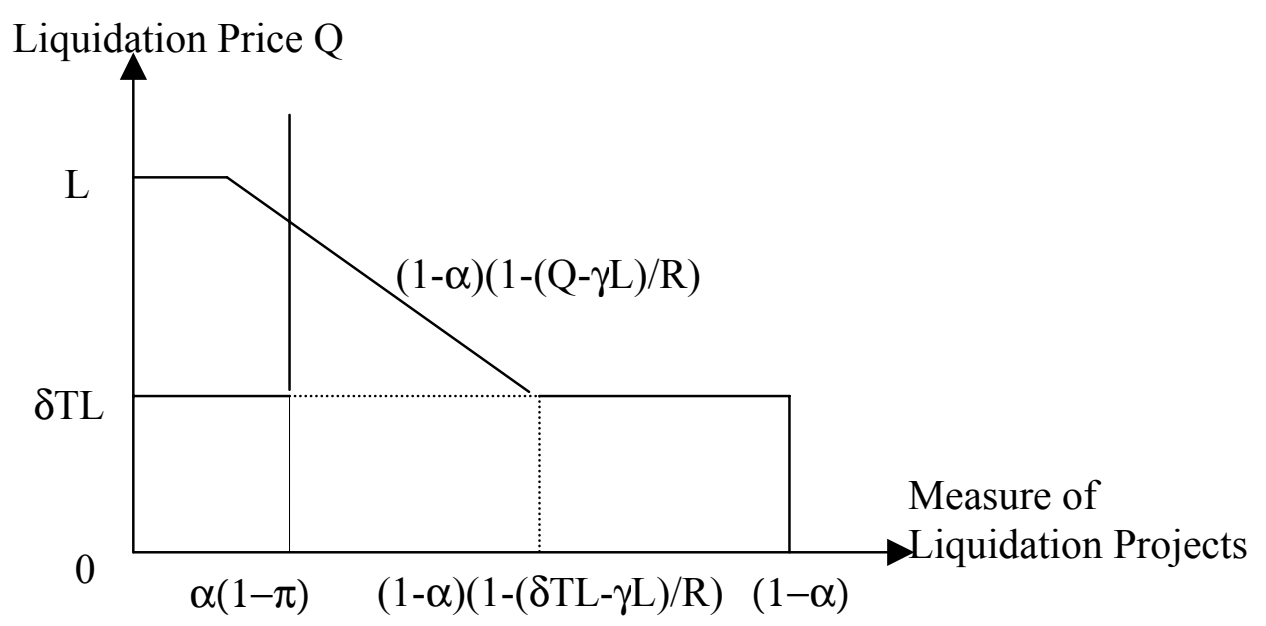

Figure $2 . \mathrm{Q}^{*} \in[\delta \mathrm{TL}, \mathrm{L}]$

When $\alpha$ is in the intermediate range, liquidity demand curve intersects liquidity supply curve when it is still sloped down. The liquidation price is between $\delta \mathrm{TL}$ and $\mathrm{L}$ the liquidity premium is between zero and L- $\delta \mathrm{TL}$. 


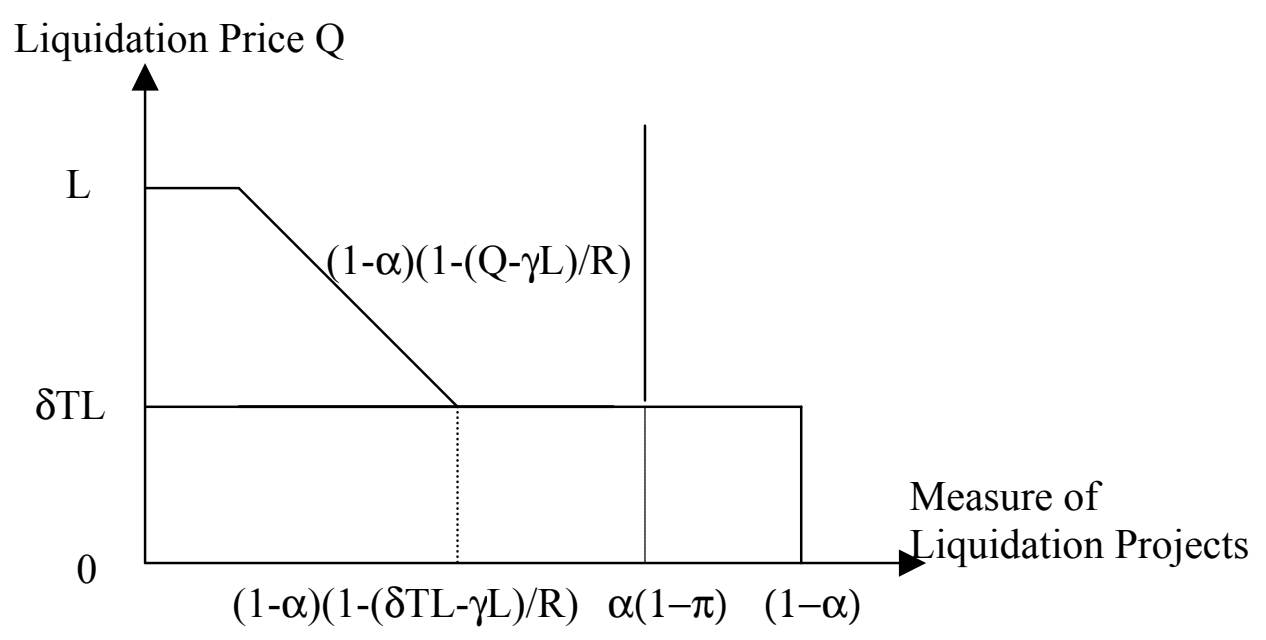

Figure $3, Q^{*}=\delta T L$

When $\alpha$ is large enough, there is excess liquidity demand in the liquidation market. The liquidation price is equal to the continuation value of the project with risk being added and the liquidity premium is at its maximum L- $\delta \mathrm{TL}$. 